\title{
More than Decisions: Reviews of American Law Reports in the Pre-West Era*
}

\begin{abstract}
Richard A. Danner ${ }^{* *}$
In the early nineteenth century, both general literary periodicals and the first American legal journals often featured reviews of new volumes of U.S. Supreme Court and state court opinions, suggesting their importance not only to lawyers seeking the latest cases, but to members of the public. The reviews contributed to public discourse through comments on issues raised in the cases and the quality of the reporting, and were valued as forums for commentary on the law and its role in American society, particularly during debates on codification and the future of the common law in the 1820s. James Kent saw the reports as worthy of study by scholars of taste and literature, or to be read for their drama and displays of great feeling. By the 1840s fewer lengthy reviews of reports were published in the journals, but shorter reviews continued in the years prior to and after the Civil War; they largely disappeared with the emergence of West's National Reporter System and other privately published reporters in the 1880s. This paper examines role and influences of the reviews in earlier decades of the century.
\end{abstract}

Keywords: Law Journals; Law Reports; Legal Information; Reviews of Law Books; Nineteenth American Legal History

Introduction: The New Legal Literature ..............................................

Law and Lawyers in Early American Periodicals........................................ 5

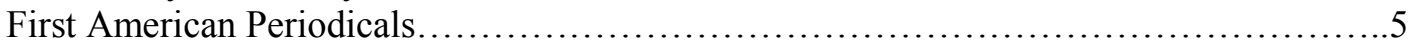

Law and Lawyers in the Early Periodicals........................................... 7

Reviews of Reports in General Periodicals ........................................... 8

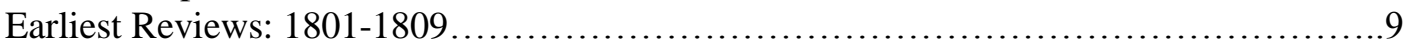

Reviews in the North American Review and Miscellaneous Journal: 1817-1830...............13

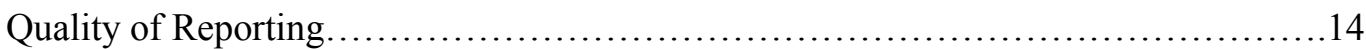

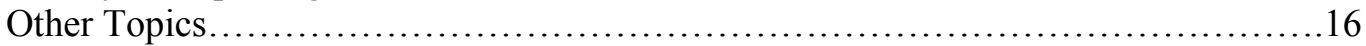

Reviews in the First Legal Periodicals....................................22

The American Law Journal and Miscellaneous Repertory ..............................2 23

The United States Law Journal...................................................... 24

The American Jurist and Law Magazine................................................26

Reviews in Later Antebellum and Post-Civil War Journals................................29

Reviews of State Court Reports..................................................... 31

The Law Reporter / Monthly Law Reporter..................................... 32

Pennsylvania Law Journal / American Law Journal............................... 34

American Law Register......................................................... 35

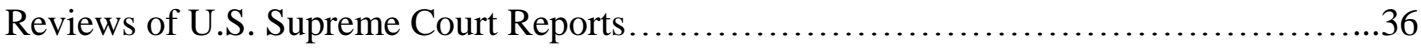

Conclusion: West's Reporters and the Journals........................................ 39

Appendix: Nineteenth Century American Legal Periodicals...............................44

* (c) Richard A. Danner 2015.

*** Rufty Research Professor of Law and Senior Associate Dean for Information Services, Duke Law School, Durham, North Carolina U.S.A. As always, I thank the reference librarians of the Goodson Law Library at Duke for their help with this paper. Special thanks to Jane Bahnson for her work compiling the list of nineteenth century American legal periodicals which provide the basis for this study and to Mike Chiorazzi for his helpful commentary. 
[Law reports] are worthy of being studied even by scholars of taste and general literature, as being authentic memorials of the business and manners of the age in which they were composed. Law reports are dramatic in their plan and structure. They abound in pathetic incident and displays of great feeling. They are faithful records of those "little competitions, factions, and debates of mankind"... They give us the skillful debates at the bar, and the elaborate opinions on the bench, delivered with the authority of oracular wisdom.

James Kent, 1 Commentaries on American Law 462-63 (1826)

\section{Introduction: The New Legal Literature}

Alfred Konefsky identified three features of the new American legal literature that emerged in the early nineteenth century. The first was the "proliferation" of published law reports which began after state courts and legislatures started appointing official reporters to oversee publication of the opinions issued by their highest courts. ${ }^{1}$ James Kent wrote that when he was appointed to the New York Supreme Court in 1898: "I never dreamed of volumes of reports and written opinions. When I came to the Bench there were no reports or State precedents." ${ }^{2}$ By 1821, however, Joseph Story could cite the then-150 volumes of published reports as evidence of the "remarkable" progress of American jurisprudence. For Story the concern was now less with a lack of reports than "that we shall be overwhelmed with their number and variety."

Konefsky next noted the extensive treatise literature heralded by the publication of Kent's Commentaries in 1826-1830, and continued in more specialized works by Story and other writers. ${ }^{4}$ The first early nineteenth-century treatises were either reprints of English texts or editions of English works published for the domestic market. ${ }^{5}$ After Story published his first treatise, on bailments, in 1832, however, original treatises on American law became the predominant form of nineteenth century legal writing, benefiting lawyers swamped by the growing mass of published case law and providing texts for students enrolled in new university law schools. ${ }^{6}$

\footnotetext{
${ }^{1}$ Alfred S. Konefsky, The Legal Profession: From the Revolution to the Civil War, in 2 CAMBRIDGE HISTORY OF LAW IN AMERICA 68, 92-94 (Michael Grossberg \& Christopher Tomlins eds., 2008).

${ }^{2}$ WiLLIAM Kent, MEMOIRS AND LETTERS OF JAMES KENT 117 (1898). Kent went on to describe his own role in developing the tradition of judges writing opinions:

In January, 1799, the second case reported in first Johnson's cases, of Ludlow v. Dale, ... I presented and read my written opinion ... and [the other judges] all gave up to me, and so I read it in court as it stands. This was the commencement of a new plan, and then was laid the first stone in the subsequently erected temple of our jurisprudence.

Id.

${ }^{3}$ Joseph Story, An Address Delivered before the Members of the Suffolk Bar, at their Anniversary, on the Fourth of September, 1821, at Boston, 1 AM. JURIST \& LAW MAG. 1, 13 (1829) [Hereinafter Story, Suffolk Address].

${ }^{4}$ See generally LaW Books IN ACTION (Angela Fernandez \& Markus D. Dubber, eds., 2012); A.W.B. Simpson, The Rise and Fall of the Legal Treatise: Legal Principles and the Forms of Legal Literature, 48 U. CHI. L. REV. 632 (1981).

${ }^{5}$ See Hugh C. MacGill \& R. Kent Newmyer, Legal Education and Legal Thought, 1790-1920, in 2 CAMBRIDGE HISTORY OF LAW, supra note 1 at $36,41-42$.

${ }^{6}$ See generally, Simpson, supra note 4 at 668-74. On the impacts of the treatises on legal education, see John H. Langbein, Law School in a University: Yale's Distinctive Path in the later Nineteenth Century, in HISTORY OF THE YALE LAW SCHOOL: THE TERCENTENNIAL LeCTURES 53, 54-56 Anthony T. Kronman, ed., (2004); John H. Langbein, Blackstone, Litchfield, and Yale: The Founding of Yale Law School, in HISTORY OF THE YALE LAW
} 
Third, Konefsky cited the new legal periodicals of the first decades of the century. Although most of the specialized legal journals "were utilitarian, printing early notices of decided cases, book reviews of new treatises, or surveys of new statutes," "Konefsky found that some had higher aspirations. The first was the American Law Journal and Miscellaneous Repertory, published intermittently in Philadelphia between 1808 and $1817,{ }^{8}$ which primarily published texts of recent cases, but also included occasional biographies, short commentaries, anecdotes, speeches and reviews of new books.

Among the books reviewed in the American Law Journal were two volumes of reports, reprinted from a literary monthly. ${ }^{9}$ Before 1830, general literary periodicals often reviewed new volumes of reports, an indication that reports of new decisions were important not only to lawyers, but to members of the public. ${ }^{10}$ In a history of early case reporting in the United States, Denis Duffey writes that publishing the reports subjected the actions of courts to regular analysis and criticism, and domesticated what they did. "No longer a matter of lawyers and judges applying alien, abstract, rigid doctrines in courtrooms, reports made the common law part of an ongoing, communal discussion conducted in the light of day." 11 Reviews of the reports contributed to public discourse by commenting on issues raised in the cases and the quality of the reporting, and as expressions of "[c]ontemporary attitudes about the place of the reports in the changing legal landscape."12

For most of the nineteenth century, nearly all published reports were compiled by individual reporters with little or no competition within their jurisdictions, and usually appeared well after the cases they contained had been decided. The reporters, whose names typically appeared on the spines of the volumes and were used for citation, often had significant discretion about what to include. ${ }^{13}$ Ephraim Kirby, the compiler of the first published volume of American reports in 1789,

SCHOOL, supra at 17, 49, n. 129 ("Kent and Story..., by turning their [lectures] into texts, facilitated the shift to the textbook-based system of instruction that characterized the early university law schools."

${ }^{7}$ Konefsky, supra note 1 at 94 . All but a few of the 112 or so American law journals starting publication prior to 1880 included either complete texts or substantial digests of decided cases.

${ }^{8}$ A subsequent volume was published in 1921 under the title Journal of Jurisprudence, See G.G. [George Gibbs], Digests of American Reports and American Law Periodicals, 23 AM. JURIST \& L. MAG. 128, 135 (1840). For a suggestion that author "G.G." was Boston attorney George Gibbs, see Notes of New Law Books, 3 U.S. MONTHLY L. MAG. 355, 356 (1851).

${ }^{9}$ See infra, text accompanying note

${ }^{10}$ Although they reviewed new volumes of reports, literary journals such as The North American Review did not publish new cases.

${ }^{11}$ Denis P. Duffey, Jr., Genre and Authority: The Rise of Case Reporting in the Early United States, 74 CHI.-KENT L. REV. 263, 267 (1998). Duffey notes the particular appeal of judge-written opinions, which gave the American audience "comparatively unmediated contact with authoritative texts." Id. at 269.

${ }^{12} \mathrm{Id}$. at 263. Duffey argues that the first reports "reflect a shift from a view of common law as consisting of immemorial English customs to a view in which it consisted, at least in part, of new American practices improvable through intentional reform." Id. at 265.

${ }^{13}$ See Konefsky, supra note 1 at 92 ("The first reporters in the late eighteenth century were entrepreneurial actors meeting a perceived market; by the early nineteenth century the states and the federal government had begun to commission official law reports."). The first requirements for official reporting in the states are discussed in FREDERICK C. HICKS, MATERIALS AND METHODS OF LEGAL RESEARCH 117-118 (1923). For contemporary descriptions of the status of official reporting in state and federal courts, and the names of the reporters, see G.G. [George Gibbs], American Reports and Reporters, 22 AM. JURIST \& L. MAG. 108, 109-141 (1839) (updated at 22 AM. JURIST \& L. MAG. 401, 401-04 (1840). See generally WiLliam D. POPKIN, EvOLUTION OF THE JUDICIAL OPINION 183-236 (2007) (describing early reporting practices in the 13 original states, plus Vermont and Kentucky). 
emphasized that the audience for his collection of Connecticut Reports went beyond the bar: "As the work is designed for general use in this state, I have avoided technical terms and phrases as much as possible, that it might be intelligible to all classes of men." ${ }^{14}$ In Democracy in America, Tocqueville noted that, in the United States nearly every question becomes "sooner or later, a subject of judicial debate; hence all parties are obliged to borrow the ideas, and even the language usual in judicial proceedings, in their daily controversies." 15

In the 1820s, reviews of new volumes of reports provided platforms for debates over the benefits and possibilities of codifying the common law. ${ }^{16}$ In the 1830 s, reviews of new volumes of reports appeared less frequently in general periodicals, but continued in the new legal periodicals. The American Jurist and Law Magazine (1829-43) in particular, often published substantial reviews of reports. After its demise, other journals continued to publish reviews regularly, but longer reviews were less common. Shorter reviews of new volumes from state courts were published through the Civil War, and occasionally in a few of the new journals that started in the late 1860s and the 1870s. New volumes of U.S. Supreme Court Reports were closely critiqued and the reporters often harshly criticized.

In the last quarter of the nineteenth century, the entrance of West Publishing Company and other publishers into the market for publishing federal and state reports radically changed the environment of law publishing. ${ }^{17}$ The privately-published reports were quicker to appear, relatively inexpensive, and more standardized in approach than the official reports, putting to rest long-standing debates about content. The number of published reports and other law books continued to rise, however, prompting frequent complaints in the law journals about duplication and the "multiplicity" of reports and opinions. Lawyers regularly complained about the difficulties posed by the growth in law books from the first meetings of the American Bar Association in the 1870s until well into the next century.

This paper examines the critical reviews of individual volumes of case reports published in legal and general journals prior to the emergence of West's National Reporter System and other

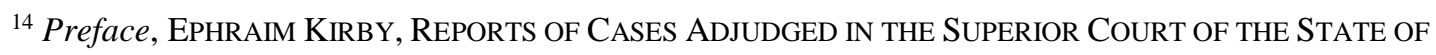
CONNECTICUT iv (1789) [hereinafter Kirby's Reports](“Some cases are reported which are merely local, and have reference to the peculiar practice of this state; these may appear unimportant to readers in other states; but they were necessary to the great object of the work." Id.).

Kirby's Reports, which included decisions of the Connecticut Superior Court from 1785-1788, are generally considered to be "the first fully developed volume of law reports published in the United States." Aumann 1938 at 339. Some argue that that Kirby's volume may have been slightly preceded by Francis Hopkinson's Reports of admiralty cases in Pennsylvania. FRANCIS HoPKInSON, JUDGEMENTS [sic] IN THE ADMIRALTY OF PENNSYLVANIA IN FOUR SUITS (1789); The debate over which was earliest is summarized in Daniel R. Coquillette, First Flower - The Earliest American Law Reports and the Extraordinary Josiah Quincy Jr. (1744-1775), 30 SUFFOLK U. L. REV. 1,2 n. 3 (1996). Coquillette notes that Dallas's Reports, published in 1790, might also be considered earliest because "it contains cases as old at 1754." Id. See also Henry Budd, Reports and Reporters, 47 AM. L. REV. 481, 513-514 (1913) ("the first regular series of reports is that of Dallas").

${ }^{15}$ AleXIS DE TOCQUEVILlE, DEMOCRACY IN AMERICA 261 (Henry Reeve, trans., 1838).

${ }^{16}$ See infra, text accompanying notes 113-146. Kenneth Smith and Susan Belasco note that in the nineteenth century, the periodical "far more than the book—was a social text, involving complex relationships among writers, readers, editors, publishers, printers and distributors." Susan Belasco Smith \& Kenneth M. Price, Introduction, in Periodical Literature in Nineteenth-Century America 3 (Kenneth M. Price \& Susan Belasco Smith, eds., 1995).

${ }^{17}$ See POPKIN supra note 13 at 101-05. 
privately published reporters. ${ }^{18}$ The second part sketches the role of lawyers in the development of American periodicals generally and in law; the third examines the reviews published in general literary periodicals in the early nineteenth century. ${ }^{19}$ The fourth part looks at reviews published in the first legal periodicals; the fifth covers changes in the reviews between 1840 and the end of the Civil War. A final part discusses the early impacts of West's National Reporter System on American law reporting, and offers observations regarding the nineteenth century practice of reviewing new volumes of reports in periodicals.

\section{Law and Lawyers in Early American Periodicals}

\section{First American Periodicals}

Periodicals are publications issued at more or less regular intervals. ${ }^{20}$ Newspapers are usually distinguished from other periodicals by their more frequent publication, ${ }^{21}$ but designations such as magazine, review, and journal are applied with less rigor. In the eighteenth century, the term magazine was used initially for periodicals which included a variety of subjects in each issue. ${ }^{22}$ Originally the term review was used for periodicals featuring articles using a recent book as the starting point for discussion, but eventually came to designate any periodical which

\footnotetext{
18 The study is based primarily on examination of the texts of articles and reviews in pre-1900 legal and general periodicals available in the HeinOnline Law Journals Library, the ProQuest American Periodicals database, JSTOR, and the LLMC-Digital Anglo-American Legal Periodicals collection. See the Appendix for a list of nineteenth century American law journals, not all of which were examined for in this study.

Other sources of information on nineteenth century legal periodicals include: Marion Brainerd, Historical Sketch of American Legal Periodicals, 14 LAW LIBR. J. 63 (1921); Michael I. Swygert \& Jon W. Bruce, The Historical Origins, Founding, and Early Development of Student-Edited Law Reviews, 36 HASTINGS L.J. 739 (1985); Erwin C. Surrency, A History of American Law Publishing 188-96 (1990); Robert C. Berring, History and Development of Law Reviews, in 1 GREAT AMERICAN LAW REVIEWs 5, 6-7 (Robert C. Berring, ed., 1984); American Law Periodicals, 2 Alb. L.J. 445 (1870); G.G. [George Gibbs], Digests, supra note 8 at 135-37; American Law Journals, 7 LAW REP. 65 (1844); 1 FrANK L. MotT, A History OF AMERICAN MAGAZINES 1741-1850, at 451-52 (1930); 2 Frank L. MOTt, A History OF AMERICAN MAGAZINES 1850-1865, at 144 (1938); 3 FranK L. MotT, A History OF AMERICAN MAGAZINES 1865-1885 (1957), at 144; 4 FRANK L. MOTT, A HistORY OF AMERICAN MAGAZINES 1885-1905, at 346-348 (1968).

${ }^{19}$ Nineteenth century reviews of published reports generally include lengthy headings with the full title of the volume under review, the dates of coverage, the names of the reporters, and publication information. In this paper I have used a short citation form for the reviews, which includes these elements: 1) name of reviewer (if known); 2) name of reporter; 3) standardized title for the reports; and 4) date of publication (if given in the review), plus the location and date of the review. E.g.: [John Gallison] Review of Henry Wheaton, U.S Reports (1816), 5 N. AM. REV. \& MisC. J.110 (1817). (In the example, Gallison's name was not published with the review, but is known from other sources.)

${ }^{20}$ Publications that appear only "occasionally" or "every now and then" may still be considered to be periodicals. 1 MoTT, supra note 18 at 5 n. 96.

${ }^{21}$ Frank Mott excludes newspapers from his study of American magazines, but does so on the basis of common usage rather than on frequency of publication. 1 MoTT, supra note 18 at 6 . Fred Hicks defined newspapers as "periodicals that appear at intervals of not more than a week. Hicks, supra note 13 at 163 . This study includes reviews in periodicals published on a weekly basis. On American legal newspapers, see Carlton Kenyon, Legal Newspapers in the United States, 63 LAW LIBR. J. 241 (1970); Surrency, supra note 18 at 195-96; American Law Periodicals, supra note 18 at 447, 449-50.

221 MoTT, supra note 18 at 39 ("The word magazine meant miscellany to most eighteenth century readers, and, with certain notable exceptions, the magazines maintained that tradition." Id. at 40-41.). The term originated from the idea of magazines as storehouses. Id. at 6-7.
} 
published serious articles. The term journal is usually reserved for serious or technical publications, such as learned and professional journals. ${ }^{23}$

The earliest American magazines were published in Philadelphia in January $1741 .{ }^{24}$ The first was the American Magazine, of A Monthly View of the Political State of the British Colonies, published by Andrew Bradford; the other, Benjamin Franklin's General Magazine, and Historical Chronicle, For all the British Plantations in America. The American Magazine produced three issues before ceasing publication; the General Magazine six. ${ }^{25}$ Short runs were typical of the eighteenth century; sixty percent of American magazines started between 1741 and 1794 lasted less than a year. ${ }^{26}$ In the first issue of his own American Magazine, which published eleven issues in 1787-1788, Noah Webster wrote "The expectation of failure is connected with the very name of a Magazine." 27

The problems facing eighteenth century American periodical publishers included: the small literate population, few authors willing to write for "new and tenuous ventures"; unreliable distribution systems, difficulties in printing and manufacturing", ${ }^{28}$ the need to rely on subscription income; competition from newspapers; and the perception that their efforts were merely "rather pale imitations of (or unabashed lootings from) the British reviews." 29 Yet, magazine publishing appealed to colonial printers because magazines gave them "rights to hold the doors to the virtual club, the periodical coffeehouse, and the ability to provide access to a still larger conversation...."30

Postal acts passed in the 1790 s improved distribution through the mail, ${ }^{31}$ and laid the groundwork for more stability and rapid growth in the early decades of the nineteenth century. ${ }^{32}$ Many general interest magazines were published, but increasing numbers of specialized

${ }^{23} \mathrm{Id}$. at 7-8.

${ }^{24}$ In 1921 Marion Brainerd would write: “As far back as 1741 the genus periodical had made its appearance on American soil, and many were the legal flowers which bloomed upon its branches." Brainerd, supra note 18 at 63.

251 MOTT, supra note 18 at 24. The competition between Bradford and Franklin is described in JARED GARDNER, The Rise AND FAll OF EARly AMERICAN MAGAZINE Culture 54-62 (2012). Gardner also suggests that the New England Courant (1721-1726), a weekly newspaper published in Boston by Franklin's brother James, was "arguably the first "magazine." Id. at 49.

261 MotT, supra note 18 at 21.

27 [Noah Webster], Acknowledgements, 1 AM. MAG. 130, 130 (1888), quoted in 1 MotT, supra note 18 at 13.

${ }^{28}$ Smith \& Price, supra note 16 at 4. Similar factors are listed in 1 MOTT, supra note 18 at 13.

${ }^{29}$ Andie Tucher, Newspapers and Periodicals, in AN EXTENSIVE REPUBLIC: PRINT, CULTURE, AND SOCIETY IN THE NEW NATION 1790-1840, 389, 397 (Robert A. Gross \& Mary Kelley, eds.,2010) (2 A History of the Book in America).

${ }^{30}$ GARDNER, supra note 25 at 54.

${ }^{31}$ On the Post Office Act of 1792, see RICHARD R. JOHN, SPREADING THE NEWS: THE AMERICAN POSTAL SYSTEM FROM FRANKLIN TO MORSE 25-63 (1995). On the importance of the Postal Act of 1794 for magazine distribution, see 1 MoTT, supra note 18 at 119-121. John points out that "though magazines enjoyed lower rates than letters following their admission into the mail in 1794, they remained far more expensive than newspapers and, unlike letters and newspapers, could always be excluded if they should prove burdensome." JOHN, supra at 39.

32 JOHn TEBbel \& MARY ELLEN ZuCKERMAN, THE MAGAZINE IN AMERICA: 1741-1990 at 9 (1991) ("Early nineteenth-century magazines proliferated until nearly every town of any consequences in America could boast a weekly literary miscellany of some kind...”). 
periodicals were started as well. Nearly one hundred magazines were being published in $1825,{ }^{33}$ many aimed at specialized and niche markets. ${ }^{34}$ They still frequently relied for content on material first published elsewhere. ${ }^{35}$ In 1831 the Illinois Monthly Magazine declared a "golden age of periodicals," including law as one of the subjects which now resorted "to this mode of enlightening the public mind." 36

\section{Law and Lawyers in the Early Periodicals}

Post-Revolution magazines frequently lampooned doctors and members of other professions, but showed particular antagonism toward lawyers in part because of their role in debt collection. ${ }^{37}$ In the early nineteenth century, however, the legal profession began to rise from what Perry Miller called "its chaotic condition of around 1790 to a position of political and intellectual domination." 38 In Democracy in America, Tocqueville saw American lawyers as forming "the highest political class, and the most cultivated circle of society" 39

Robert Ferguson describes "a now forgotten configuration of law and letters that dominated American literary aspirations from the Revolution until the fourth decade of the nineteenth century," 40 noting "Miller's insistence that lawyers and legal thought were crucial to literary

331 Motт, supra note 18 at 120 . Mott marks 1825 as the end of the "second period of magazine development in America," Id. at 124, citing the suspension of publication of Port-Folio in 1827 and the enactment of the Postal Act of 1825 . He suggests that by 1850 about 600 "periodicals other than newspapers" were being published in the U.S. $I d$. at 342 . He notes, however, that the available figures for the period "are fragmentary and unreliable." Id., n. 6. See also Jeffrey D. Groves, Periodicals and Serial Publication: Introduction, in THE INDUSTRIAL BOOK IN AMERICA 224-225 (Scott E. Casper, et al, eds., 2007) (3 A History of the Book in America) (describing problems in using census data to count periodicals). Mid-century commentators spoke of Americans' "magazine mania." Eric Lupfer, The Business of American Magazines in THE INDUSTRIAL BOOK IN AMERICA, supra at 248, 249. Most magazines failed: "Indeed, most were risky ventures - undercapitalized, poorly advertised, haphazardly managed, and with limited circulation." Id. at 250.

${ }^{34}$ GARDNER, supra note 25 at 159.

${ }^{35}$ Prior to the Civil war "the lack of international copyright made literary piracy highly profitable. It was practiced by magazine and book publishers alike, by most quite openly." Id. at 52. The practice began to be curbed in 1845 when Graham's Magazine and Godey's Lady's Book started to copyright their content. Id. at 70; 1 MoTT, supra note 18 at 503 .

${ }^{36}$ Periodicals, 1 Illinois Monthly Magazine 302, 302 (1831), quoted in 1 MoTT, supra note 18 at 341 . Not everyone was enthusiastic about magazines. Philadelphia lawyer Charles Ingersoll, who was also an author, wrote in 1810: "The magazines, reviews, and newspapers that are spreading over the face of Europe and North America, threaten to deface and obliterate every vestige of the good sense and information to be derived from well chosen [sic] reading and unprejudiced inquiry." CHARLES JARED INGERSOLL, INCHIQUIN, THE JESUIT LETTERS 126 (1810), quoted in LARZER ZIFF, WRITING IN THE NEW NATION 99 (1991).

${ }^{37} 1$ MotT, supra note 18 at 58-59. See also JeFFREY L. PASLEY, THE TYRANNY OF PRINTERS: NEWSPAPER POLITICS IN THE EARLY AMERICAN REPUBLIC 271-74 (2001) (describing antagonisms between lawyers, and newspaper editors and publishers).

38 PERry Miller, THE LIFE OF THE Mind IN AMERICA 109 (1965).

39 TOCQUEVILLE, supra note 15 at 259.

${ }^{40}$ RoBERT A. FERGUSON, LAW AND LETTERS IN AMERICAN CUlTURE 5 (1984) (suggesting that "[h]alf of the important critics of the day trained for law, and attorneys controlled many of the important journals."). See also DAVID DOWLING, CAPITAL LETTERS: AUTHORSHIP IN THE ANTEBELluM LiTERARY MARKET 3 (2009) (arguing that "the vast majority of American writers of the first half of the century (and even earlier) had been trained in law or politics").

See FERGUSON, supra at 66-72 for discussion of the importance of general learning and literature to the antebellum bar. For an examination of the thinking of early nineteenth century lawyers with literary interests, see 
development in the antebellum period." ${ }^{41}$ In the first quarter of the century, Mott found that "[a]s contributors, editors, and patrons of magazine literature no other profession furnished as much good material as the law," and that lawyers made up most of the management of general magazines and reviews. ${ }^{42}$

Joseph Dennie ${ }^{43}$ the founder of Port-Folio (1801-1827), perhaps the pre-eminent magazine of the first quarter of the century, ${ }^{44}$ claimed that his publishing efforts had "been most ably seconded by the lawyers of the country; men who are unquestionably the best patrons which literature can hope to find in America." 45 John E. Hall, editor of the first U.S. legal periodical, the American Law Journal and Miscellaneous Repertory (1808-17) contributed to and for a time edited Port Folio. Daniel Webster and James Kent were corresponding members of the Monthly Anthology and Boston Review (1803-1811). New England lawyers Willard Phillips, John Gallison, Richard Henry Dana, Edward T. Channing, and William P. Mason were active with the North American Review (1815-present). ${ }^{46}$ Mott notes that in the early 1820s, "Law was a well-tilled field

Richard Beale Davis, The Early American Lawyer and the Profession of Letters, 12 HunTINGTON LIBR. Q. 191 (1949). Gilman Ostrander found that "[t]he best of America's lawyers were seen to be delving through the civilizations of Greece, Rome, and medieval and modern Europe as well as England in the service of legal wisdom." GILMAN M. OSTRANDER, REPUBLIC OF LETTERS: THE AMERICAN INTELLECTUAL COMMUNITY, 1776-1865 at 104 (1999). Bryan Waterman argues that James Kent and his associate, New York Supreme Court Reporter William Johnson, believed that knowledge of the law "depended on the 'root' of broad classical learning, including familiarity with belles lettres." BRYAN WATERMAN, REPUBLIC OF INTELLECT: THE FRIENDLY CLUB OF NEW YORK CITY AND THE MAKING OF AMERICAN LITERATURE 148 (2007).

Catherine Kaplan notes the roles played by Kent and Johnson in the national "quest to collect and diffuse information and create a community of intellect.” CATHERINE O'DONNELL KAPLAN, MEN OF LETTERS IN THE EARLY REPUBLIC 231-2 (2008). Kent's own early reputation was secured through Johnson's efforts as court reporter to publish the volumes of New York opinions. For Waterman, "Kent's most stunning exploitation of the early republic's literary culture" was his role in the development of written judicial opinions and published reports. The reputation afforded the decisions he wrote "allowed for both the appearance of a native legal authority and tradition, and for ensuring that common law traditions would form the heart of American jurisprudence." WATERMAN supra at 152. The two were linked throughout their careers. See John H. Langbein, Chancellor Kent and the History of Legal Literature, 93 COLUM. L. REV. 547, 578-84 (1993).

${ }^{41}$ FERGUSON, supra note 40 at 8, citing MiLLER, supra note 38 at 93-95, 100, 121-24, 133-38.

421 MotT, supra note 18 at 154-55. See also JEAn V. MATTHEWs, TOWARD A New SocietY: AMERICAN THOught AND CULTURE, 1800-1830 at 53 (1990) ("Lawyers ... dominated literature, turning out most of the essays, poetry, criticism, history, and biography of this period.).

${ }^{43}$ (Dennie law at Harvard, although one of his friends noted that Dennie's "legal knowledge consisted wholly in a choice selection of quaint, obsolete, and queer phrases from 'Plowden's Commentaries,' the only law book he had ever read with any attention...." KAPLAN, supra note 40 at 114 (quoting Jeremiah Mason).

In 1803 Dennie was indicted for seditious libel for anti-democratic comments published in the Port-Folio. See 1 MотT, supra note 18 at 228-30. After being acquitted, he used the magazine to report on his trial. Sketch of the Editor's Trial, 5 PORT-FOLIO 402 (1805).

${ }^{44}$ See 1 MoTT, supra note 18 at 123.

${ }^{45}$ John T. Queenan, "The Port Folio: A Study of the History and Significance of an Early American Magazine" 3 (1955) (quoting New ProsPeCtUS, Jan. 1806 at 2) (unpublished Ph.D. dissertation, University of Pennsylvania) (available through ProQuest Dissertations \& Theses). Queenan found that the magazine "was to a great extent a product of the intellectual efforts of Philadelphia lawyers," and it was "difficult to see how the Port Folio could have weathered the first few years without [their] contributions.... Id. at 3. For a list of lawyer supporters, see KAPLAN, supra note 40 at 143 n.3.

${ }^{46}$ See 2 MOTT, supra note 18 at 224. 
in the Review; Joseph Story, Henry Wheaton, and Theron Metcalf composed, with the lawyer members of the club, a distinguished legal staff for the Journal.",47

\section{Reviews of Reports in General Periodicals}

The first periodical reviews of volumes of reports appeared in the American Review, and Literary Journal (1801-1802); Port-Folio; and the Monthly Anthology, and Boston Review (18031811) between 1801 and 1809 (a time when there were still only a few volumes of domestic reports). ${ }^{48}$ After 1809, it seems that no further reviews of reports were published in periodicals until 1817, when they began to be featured with some regularity in the North American Review and Miscellaneous Journal (1815-date), and occasionally in other journals and reviews.

\section{Earliest Reviews: 1801-1809}

In the early nineteenth century, the court reporter was a figure of consequence: "the person who selected the cases, stated the facts, summarized the views of counsel, summarized the views of those judges who gave oral opinions, and supplied annotations of his own." 49 The reviewers of published reports sometimes discussed broader topics related to the cases, but mostly they focused on how well the reporters chose and presented what they published, ${ }^{50}$ and such questions as: How fully were (or should) arguments of counsel reported $?^{51}$ How accurate were the statements of fact? How well did the syllabi or headnotes summarize the meaning of the case? Should all the cases have been included? Was the reporter engaging in "book-making" by padding a volume with unnecessary material $?^{52}$ They did not always agree on which elements of a case were most important.

${ }^{47} I d$. at 228.

${ }^{48}$ In 1923 Hicks counted but five volumes of American reports in 1801 and eighteen in 1810. HICKS, supra note 13, at 111. As noted below the first American legal periodical, the American Law Journal and Miscellaneous Repertory, reprinted two reviews of reports from The Monthly Anthology, and Boston Review in 1808 and 1809. See infra note 164.

${ }^{49}$ Langbein, Chancellor Kent, supra note 40 at 578. For comparisons of the role of the reporter in the early nineteenth century to what it would be later, see id. at 576-78; POPKIN, supra note 13 at 101-105.

50 The parts of a case are generally considered to include the title, which provides the names of the parties; a statement of the case or the facts (perhaps to include brief treatments of the pleadings, evidence, and procedure in a lower court); the syllabus (or headnote), usually written by the reporter, which summarizes the proposition(s) of law decided in the case; the opinion or opinions of the court; and a brief statement of the decision. Some early reviews used the terms "marginal epitome" or "marginal notes" to describe the reporter's summaries. In the nineteenth century case reports also frequently included the arguments of counsel in full or in summary. For discussion of the parts of cases in the earliest text books on legal research and bibliography, see BRIEF MAKING AND THE USE OF LAW BoOKS 74-75 (Nathan Abbott, ed., 1906); HICKS, supra note 13 at 81-82; LAW BoOKS AND THEIR USE $32-34$ (1924); Fred A. AldEAN, How TO Find THE LAW 437-442 (1931).

51 The question of how thoroughly the arguments should be presented had been noted as early as 1789 in the preface to Kirby's Reports. See Kirby's Reports, supra note 14 at iv ("In these Reports, ... I have not stated the pleadings or arguments of counsel further than was necessary to bring up the points relied on, except some few instances which seemed to require a more lengthy detail of argument."). The matter would continue to be discussed through most of the nineteenth century.

52 See Review of Dudley Tyng, Massachusetts Reports (1806), 4 MonTHLy ANTHOLOGY, AND BostON REV. 435 , 435-36 (1807). 
The American Review, and Literary Journal (1801-1802) reviewed several volumes of federal and state court reports, emphasizing that a reporter's "principle merit" was to include only useful cases and accurate stating facts and arguments. ${ }^{53}$ An 1801 review of decisions from the New York Supreme Court found the cases "to be divested of useless circumstances and needless arguments; the points to be decided are presented distinctly to view, and the opinion of the court expressed with requisite clearness and precision." 54 A volume of Pennsylvania opinions was praised for its "perspicuity" (a trait favored by early reviewers) in reporting county court cases, but criticized for including too many jury charges. ${ }^{55}$ The reviewer of a set of cases decided by the Court of Appeals of Virginia praised the reporter for aiming "to give a correct statement of [the cases], and to make a true report of the arguments, and decisions upon them. ${ }^{56}$

In 1802, the American Review reviewed the first three volumes (1790, 1798, 1799) of Alexander Dallas's reports of cases from Pennsylvania and the U.S. Supreme Court. ${ }^{57}$ The reviewer found that no prior reports "equaled in value and respectability the one now before us"; yet, he was sometimes "fatigued by the prolix reasonings of the advocates and of the court," and the comprehensive references to authorities by the attorneys. ${ }^{58}$ In the same year, a review of John Wallace's reports of cases from the federal third circuit criticized the reporter for including too much detail on cases dealing with procedure, and because the arguments of counsel and the opinions were too long: "the latter are given separately, even where the decision is unanimous, which ought only to be done where the judges differ." 59

${ }^{53}$ See Review of William Coleman, New York Reports (1791-1800), 1 AM. REV. \& LITERARY J. 39, 40 (1801).

${ }^{54} I d$. at $40-41$.

${ }^{55}$ Review of Alexander Addison, Pennsylvania Reports (1800), 1 AM. REV. \& LITERARY J. 180, 181-82 (1801).

${ }^{56}$ Review of Bushrod Washington, Virginia Reports (1798), 1 AM. REV. \& LITERARY J.413, 414 (1801) (italics in original). Washington had been appointed to the U.S. Supreme Court by the time the reports were published.

${ }^{57}$ Review of Alexander Dallas, U.S. \& Pennsylvania Reports (1790, 1798, 1799), 2 AM. REV. \& LITERARY J. 26 (1802).

The position of Supreme Court Reporter was not made official until 1817, 3 Stat. 376, ch. 63 sec. 1 (1817). For discussion of the slow process of enacting the law creating the position, see Craig Joyce, The Rise of the Supreme Court Reporter: An Institutional Perspective on Marshall Court Ascendancy, 83 MicH. L. REV. 1291, 1342-47 (1985). Morris Cohen and Sharon O'Connor suggest that the second reporter, William Cranch (1802-1817), held an appointment from the Court. See MORRIS L. COHEN \& SHARON HAMBY O'CONNOR, A GUIDE TO THE EARLY REPORTS OF THE SUPREME COURT OF THE UNITED STATES 2, 29 (1995). But see Joyce, supra at 1347 ("Without doubt, the reports published by Cranch, like the volumes of his predecessor, remained at all times a private venture."). In 1834, the U.S. Supreme Court ordered the filing of written opinions with the clerk, but did not require that all opinions be written. See id. at 1298, n. 46 (citing 33 U.S. (8 Peters vii (1834). See also POPKIN, supra note 13 at $76-80$.

${ }^{58}$ See Review of Dallas's Reports (1790, 1798, 1799), supra note 57 at 27. Joyce suggests that Dallas looked to Kirby's Reports as a model. Joyce, supra note 57 at 1299. For discussion of the sources for Dallas's Reports and criticisms of his efforts, see $i d$. at 1303-06. See also G. EDWARD White, The MARShall COURT AND CUltural CHANGE, 1815-1835 at 385, n. 3 (2010); WILlIAM DOMNARSKI, IN THE OPINION OF THE COURT 7 (1996) (severely criticizing both Dallas and his successor William Cranch).

${ }^{59}$ Review of John Wallace, U.S. Third Circuit Reports (1801), 2 AM. REV. \& LITERARY J. 72, 73 (1802). The reviewer noted that "The business of reporting is ... new in our country, and great allowance is due to a first essay." Id. at 74 .

The reviewer also set forth a list of what a reporter should include:

A correct statement of the case, an analysis of the arguments of counsel presenting the questions raised, the principles contended for, the authorities read and relied upon, a summary sketch of the reasoning at the bar upon each head, with the opinion of the court, expressed as concisely as is consistent with perspicuity.... Id. at 73 . 
Dallas's fourth volume included U.S. Supreme Court cases from the 1799 and 1800 terms, but was not published until 1807, three years after his successor William Cranch's first volume (1804), which covered the 1801 and 1803 terms. A reviewer in The Monthly Anthology, and Boston Review ${ }^{60}$ observed that in his final volume Dallas had engaged in book-making, having made "the most of the materials on hand, in order that a volume of decent size might terminate his career and round off his profits." 61 Dallas had also failed to provide "marginal epitome of the cases," thereby forcing a busy lawyer "to labour through the whole of a long case to ascertain, whether a single principle has been determined by it or not." 62

Cranch's first volume of Supreme Court Reports prompted a lengthy review in the Port-Folio, which analyzed several cases, including Marbury v. Madison. ${ }^{63}$ The reviewer noted that because the Court required written opinions on "all questions [of] difficulty and importance," the reporter's task for opinions had become "merely that of a copyist." 64 As a result, Cranch's work could be judged only on the basis of his statements of cases and presentation of the arguments. On those components, his efforts "possess[ed] the characters, most essential to this species of compilation: they are clear, methodical, and correct: neither obscured by brevity, nor perplexed with diffuseness." 65

The Monthly Anthology also reviewed several volumes of state court reports, beginning with the first published volume of Massachusetts Supreme Court cases, reported by Ephraim Williams, ${ }^{66}$ After noting disagreements regarding best reporting styles, the reviewer concluded that "we are decidedly of opinion [sic], that modern reports are, in general, too prolix." ${ }^{67}$ Although Williams seemed to be aware of the problem, he had nonetheless included cases that were too particular to create precedent as well as overly wordy opinions, ${ }^{68}$ and like other reporters his "greatest error is on the side of prolixity." 69

In the preface to his volume Wallace explained his approach and described the difficulties he and other reporters faced. JoHn WALlaCe, U.S. THIRD CIRCUIT REPORTS (1801) [n.p.] (1801). A Port-Folio review of Wallace's Reports quoted at length from the preface. See Review of John Wallace, U.S. Third Circuit Reports (1801), 2 PORTFOLIO 1 (1802).

${ }^{60}$ Review of Alexander Dallas, U.S. \& Pennsylvania Reports (1807), Monthly ANTHOlogy \& Boston Rev. (Mar $1,1808)$, at 156.

${ }^{61}$ The reviewer cited inclusion of cases of lesser importance from lower courts, as well as "five cases reported, in which the same facts are presented for decision, and the decision is the same in all." Id. at 159.

${ }^{62} I d$. at 161.

${ }^{63}$ Marbury v. Madison, 5 U.S. (1 Cranch) 137 (1803).

${ }^{64}$ Review of William Cranch, U.S. Supreme Court Cases (1804), 4 Port-Folio 49, 49 (1804).

${ }^{65} \mathrm{Id}$. at 50.

${ }^{66}$ Review of Ephraim Williams, Massachusetts Reports (1805), 3 MONTHLY ANTHOLOGY \& Boston ReV. 138 (1806).

${ }^{67} I d$. at 140-41 (providing examples of the extent to which recent volumes of reports (including those of Dallas, Wallace, Cranch) could have been shortened). "[O]ur great objection to this work as far as Mr. W. is responsible for it, is its bulk. It size is unreasonably swelled by large type and large margin." Id. at 151 .

${ }^{68} I d$. at $140-43$. The review proposes a one paragraph replacement for a case that took up nearly six pages in the volume. Id. at 143 .

${ }^{69} I d$. at 145 . His notes on the cases were "judicious," but supplied too sparingly, some of his quotations were inexact and he left too many errors in citation and grammar. Id. at 145-46. The review ended with a long list of errata not noted by Williams. $I d$. at 152 . 
In July 1806, the Anthology reviewed a three volume set of decisions from the New York Supreme Court, finding that reporter George Caines stated the cases "with brevity, with method, and perspicuity," although the arguments of counsel were "given more diffusely than was necessary." 70 The reviewer also found grammatical errors and inaccuracies, some of which were in the opinions written by the court and not the fault of the reporter. ${ }^{71}$ "[E]very lawyer will be indebted to the reporter for his notes and marginal references" even though "some of the marginal statements are incorrect, and some unintelligible."72

In 1807, the Anthology compared Dudley Tyng's first volume of Massachusetts Reports to those of Williams, concluding that its criticisms of Williams's reports had encouraged Tyng's "more exact and more erudite labours," and that Tyng's method "meets our entire approbation."73 After noting that "it was not for us to question the judgments of the supreme tribunal of the commonwealth," the review went on to discuss the details of several cases in order to suggest "difficulties of our own, which are perhaps unfounded."74

The first reviews of American reports tended to concentrate on the reporters' choices of cases to include and the technical aspects of their presentation of the cases. Although the reviewers stated they had neither interest nor the skills to comment on the substance of the cases, sometimes they did. They favored perspicuity over prolixity, but seemed to differ on how to attain clarity in the arguments of counsel and the opinions themselves. Some used their reviews as platforms to comment on matters other than the skills of individual reporters. Although during this period there were only a few volumes of domestic reports available, the reviewers questioned whether it was necessary to publish as many cases as they found in some volumes.

Several reviews of the period emphasized the importance of publishing court decisions. The Monthly Anthology's review of Dallas's final volume saw '[t]he rapid increase of publications containing reports of cases" as proof of "the estimation in which these valuable records of judicial history are held by the publick,"75 and urged more states to publish their reports in order to foster development of a distinctive "general system of legal principles" for the U.S. ${ }^{76}$ The reviewer of Tyng's first volume pointed out the importance of accurate published reports to the public as well as to the legal profession, while noting that "[t]he multiplicity of modern law books makes it desirable to reach the point decided with as little unnecessary labour as possible."77

\footnotetext{
${ }^{70}$ Review of George Caines, New York Reports (1803-1805), 3 Monthly ANTHOLOGY \& BostON REV. 367,368 (1806).

${ }^{71}$ Id. at $368-69$.

${ }^{72} I d$. at 368 .

${ }^{73}$ Review of Tyng's Massachusetts Reports (1806), supra note 52 at 436 ("[i]t was to be expected, that the embarassments [sic] of a first attempt under a system not perfectly organized for the purpose would occasion some errors." Id.).

${ }^{74}$ Id. at 437. In 1809, the Anthology published a short review of Horace Binney's first volume of Pennsylvania Reports, remarking that Binney had improved upon his predecessor by providing an abstract for each case in the margin. Review of Horace Binney, Pennsylvania Reports (1809), Monthly ANTHOLOGy \& Boston REV.., June 1, 1809 at 420.

${ }^{75}$ Review of Dallas's U.S. \& Pennsylvania Reports (1807), supra note 60 at 156.

${ }^{76} \mathrm{Id}$. at 159.

${ }^{77}$ Review of Tyng's Massachusetts Reports (1806), supra note 52 at 435-436. This was perhaps the first instance of the term "multiplicity" to describe lawyers' concerns about the ever-growing number of law books.
} 
The review of Williams's Massachusetts Reports included a lengthy discussion of the place of the common law in American jurisprudence and the substantial role played by published opinions. A "well-executed" volume of reports provided:

more publick utility than any measure our government has adopted since the formation of the constitution. ... It serves to make the path of duty plain before the people, by making the law a known rule of conduct: and for the same reason, it diminishes litigation. It has a tendency to limit the discretion of judges; and consequently increases liberty. ${ }^{78}$

The reviewer was, however, "forcibly struck with the small number of cases and authorities cited," both in the opinions and in arguments of counsel, and expressed his hopes that this did not mean that "our learned judges are unfriendly to the use of precedents," preferring to rely on their own reasoning abilities. ${ }^{79}$ The following year, an Anthology review of Johnson's New York Reports again noted the importance of well reported cases and adherence to precedent to the development of American jurisprudence. ${ }^{80}$ The review of Johnson's Reports also emphasized the importance of unanimous opinions, finding that while there were only twenty difficult cases in the volume, the court had disagreed on five of them. ${ }^{81}$ That of Williams's Reports highlighted the number of separate opinions issued in Massachusetts, and connected multiple opinions to the court's failure to pay attention to precedent. ${ }^{82}$

\section{Reviews in the North American Review and Miscellaneous Journal: 1817-1830 ${ }^{83}$}

G. Edward White describes an "informal network" of judges, treatise writers, reporters, and legal educators which flourished around Joseph Story from 1815-1835, and worked to facilitate publication of judicial opinions, digests, and treatises; secure judgeships, reporterships, and professorships for those pursuing scientific study of the law; and review each other's works." 84

\footnotetext{
${ }^{78}$ Review of Williams's Massachusetts Reports (1806), supra note 66 at 140. A review of Cranch's first volume argued that the need for accurate and authentic reports of Supreme Court cases had become "greater and more urgent" since the Court moved in 1800 from Philadelphia ("a great and commercial city") to the wilds of Washington. Review of Cranch's U.S. Reports (1804), supra note 64 at 49. On the conditions the Court faced upon its move to Washington, see GEORGE LEE HASKInS \& HERBERT A. JOHNSON, FOUNDATIONS OF POWER: JOHN MARSHALL, 1801-1815, 74-84 (1981) (II History of the Supreme Court of the United States).

${ }^{79}$ Review of Williams's Massachusetts Reports (1806), supra note 66 at 149.

${ }^{80}$ Review of William Johnson, New York Reports (1806), 4 MonTHLY ANTHOLOGY \& Boston REV. 206, 207 (1807) ("Precedents not only assist the judge; they in a good measure control him. ... They prevent the substitution of personal opinions for the doctrines of the law.").

${ }^{81} I d$. at 208.

${ }^{82}$ Review of Williams's, Massachusetts Reports (1806) supra note 66 at 150 ("Judges, who do not avail themselves of the 'light and assistance' of former precedents, will be often found differing in opinion."). The reviewer also noted that Massachusetts would "never have any thoroughly examined and well-digested determinations" as long as the judges were forced to travel throughout the state. Id. at 148. The 1806 reviewer of Caines's New York decisions attributed the problems posed by issuance of separate opinions to some states' practice of electing judges. Review of Caine's New York Reports (1803-1805), supra note 70 at 367-68.

${ }^{83}$ With volume 13 (1821), the title was shortened to North American Review.

${ }^{84}$ WhITE, supra note 58 at 105 . In addition to Story, White listed: John Marshall, Bushrod Washington, Joseph Hopkinson, Nathan Dane, James Kent, David Hoffman, Timothy Walker, Peter Du Ponceau, Wheaton, William Johnson, Richard Peters, William Mason, Henry Gilpin, and Simon Greenleaf. See also PETER STEIN, THE AtTraction of the Civil Law in Post-Revolutionary AMERICA 403, 415-16 (1966).
} 
Many members of this group contributed to the North American Review and Miscellaneous Journal which was established in Boston in 1815. ${ }^{85}$ A later commentator noted that the Review "was planned to appeal to all the professions, and ... the condition of the law was, of course, discussed from time to time." 86

\section{Quality of Reporting}

In its second volume, the North American Review published its first review of a law book, Henry Wheaton's Digest of the Law of Maritime Captures and Prizes. ${ }^{87}$ Reviewer Alexander Townsend noted the quality of Wheaton's effort, emphasizing how necessary digests had become in light of the increasing evil posed by the growth in number of law. ${ }^{88}$ In 1816 Wheaton became the third reporter of U.S. Supreme Court decisions. ${ }^{89}$ John Gallison reviewed the first volume of Wheaton's Reports in the North American Review. Gallison noted that, when judges provided written opinions, a reporter was left with little to do "but to give a clear statement of the facts, and an accurate and faithful account of the arguments of counsel." 90 He was disappointed in Wheaton's presentations of the arguments of counsel, finding them to be inconsistent, sometimes "stating positions, rather than the reasoning and illustrations, by which they are supported," criticized Wheaton's attempts to capture in print the flourishes of oral arguments. ${ }^{92}$ Gallison praised Wheaton for his notes on important points in the cases, particularly those relating to

${ }^{85}$ One historian of nineteenth-century American periodicals writes that "the establishment of the North American Review ... marks the beginning of American literature." HENRY M. AldEN, MAGAZINE WRITING AND THE NEW LITERATURE 44 (1908). Mott describes connections between the new Review and the Monthly Anthology, which had ceased publication in 1811. 2 MOTT, supra note 18 at 220-21.

${ }^{86}$ F.W.G. [Frank W. Grinnell], Some Forgotten Massachusetts History about Codification and its Relation to Current Legislative and Judicial Problems. 1 MAss. L. Q. 319, 322 (1916) ("Books, pamphlets and addresses, law reports, etc., were reviewed and discussed." Id.). In 1829 the American Jurist and Law Magazine questioned the general reviews' enthusiasm for the law, noting that "some portions of the [leading reviews] have been occupied with legal subjects ... not without some hesitation on the part of the part of the conductors of the reviews, and, in some instances, to the prejudice of their popularity." To the Public, 1 AM. JURIST \& L. MAG. i, i (1829).

${ }^{87}$ [Alexander Townsend], A Digest of the Law of Maritime Captures and Prises [sic], 2 N. AM. REV. \& Misc. J. 218, 218 (1818).

Articles in the North American Review were published anonymously until 1868. See 2 MotT, supra note 18 at 249. But most early authors can be identified through William Cushing, Index to the North American Review: Volumes I-CXXV, 1815-1877 (1878), reprinted in KENNETH WALTER CAMERON, RESEARCH KEYS TO THE AMERICAN RENAISSANCE 83-160 (1967). Unless otherwise noted, Cushing's Index is the source of authors' names identified in this paper. See also HoraCE E. SCUDDER, JAMES RuSSELl LOWELl; A BIOGRAPHY 421 (1901) quoted in ALgERnON TASSIN, THE MAGAZINE IN AMERICA 316 (1916) ("The North American used to print a little slip with the authorship of the separate articles set against the successive numbers of the articles; and this slip, although not inserted in all the copies sold or sent to subscribers, was at the service of newspapers and the inner circle."). Mott provides lists of frequent authors, including many lawyers, in his history of the Review. See, e.g., 2 MotT, supra note 18 at 227-28, 232. See also Appendix: The Semi-Centenary of the North American Review, 100 N. AM. REV. 315 (1865). Story's contributions are identified and collected in JOSEPH STORY, THE MISCELLANEOUS WRITINGS OF JOSEPH STORY (William W. Story, ed.) (1852)

${ }^{88}$ [Townsend], supra note 87 at 218.

${ }^{89}$ Wheaton's tenure as Supreme Court reporter is discussed in WHITE, supra note 58 at 388-405.

${ }^{90}$ [John Gallison] Review of Henry Wheaton, U.S Reports (1816), 5 N. AM. REV. \& MisC. J. 110, 113 (1817).

${ }^{91} \mathrm{Id}$. at 117.

${ }^{92} I d$. at 117-18. ("Mr. Wheaton has, we think, been unfortunate in attempting sometimes to preserve the coruscations of fancy, with which the orator has sought to decorate his discourse."). One such attempt was described as "the broken and disjointed limbs of a form once beautiful." Id. at 118. 
maritime and admiralty law notes, and compared them favorably to the commentary "found in the most approved foreign writers." 93

In 1818 Daniel Webster reviewed Wheaton's third volume, ${ }^{94}$ observing that Wheaton had fallen victim to the reporters' "rage for book-making," which had spawned a "growing habit of reporting cases not sufficiently important to merit publicity." "95 Webster suggested that Wheaton omit cases "turning merely upon evidence" and curtail publication of records unless necessary, but said of his notes to the cases: "No reporter in modern times, as far as we know, has inserted so much and so valuable matter of his own." 96

From 1818 through 1828, the North American Review published reviews of reports issued by state and federal courts in New England and New York. ${ }^{97}$ In 1818, Theron Metcalf reviewed the latest volume of Tyng's Massachusetts Reports, pointing out that Massachusetts had in 1804 taken the lead in appointing an official reporter, but how rare it remained. ${ }^{98}$ Metcalf noted Tyng's wellestablished reputation as a reporter and his skill in presenting oral arguments, ${ }^{99}$ and that his success in providing succinct statements of facts, points made and authorities cited in argument, and full length opinions. ${ }^{100}$ Metcalf argued against separate opinions, and strongly in favor of written

${ }^{93} I d$. at 114. Wheaton's Reports were notable for his extensive annotations, mostly on matters regarding prize and admiralty law. See e.g. The Mary and Susan, 14 U.S. (1 Wheaton) 46, 55 n. f (1816) (commenting on "[t]he effect of domicil ... on national character"). For discussion of Wheaton's "scholarly notes" see WHITE, supra note 58 at $402-$ 03. Some notes in Wheaton's Reports were written by Justice Story. Id. at 391.

94 The second volume was not reviewed. White notes that "none of Wheaton's professional admirers seemed inclined to review his volumes in print, and Wheaton had to enlist Story to procure [Webster's] review" of his third volume. Id. at 403.

95 [Daniel Webster], Review of Henry Wheaton, U.S. Reports (1818), 8 N. AM. REV. \& MISC. J. 63, 68 (1818). ${ }^{96} \mathrm{Id}$. at 71.

Later reviews of Wheaton's Reports in the North American Review focused less on the quality of his reporting than on the substance of the cases he reported. An 1820 review of Wheaton's fourth volume focused exclusively on the Dartmouth College case, 17 U.S. (4 Wheaton) 518 (1819). See [W. Dutton], Report of the case of the Trustees of Dartmouth College against William H. Woodward, 10 N. AM. REV. \& MISC. J. 83 (1820) (reviewed along with a separately published report of the case by Timothy Farrar). Wheaton's seventh volume was reviewed by Theron Metcalf, who wrote "It is not our purpose to analyze the book before us; nor will be enlarge upon the manner in which the reporter has executed the task which peculiarly belongs to him." [Theron Metcalf], Review of Henry Wheaton, U.S. Reports (1822), 17 N. AM. REV. 118, 118 (1823). The eighth was reviewed in 1824 by Caleb Cushing along with volumes of reports from Massachusetts and New York. Cushing praised Wheaton "as a faithful and accomplished reporter of the decisions of the most elevated law court in the nation," and rejoiced that the Court possessed such a distinguished reporter of its decisions. [Caleb Cushing], Review of Henry Wheaton, U.S. Reports (1823); William Johnson, New York Reports (1823); Dudley Tyng, Massachusetts Reports (1820-1822),18 N. AM. REV. 371, 374 (1824).

97 The Review also reviewed Simon Greenleaf's collection of overruled cases. See [Theron Metcalf], Review of Simon Greenleaf, A Collection of Cases Overruled, Doubted, or Limited in Their Application, 15 N. AM. REV. 65 (1822), as well as Metcalf's edition of Yelverton's Reports, [Henry Wheaton], Review of Theron Metcalf, Yelverton's Reports, 16 N. AM. REV. 196 (1823).

98 [Theron Metcalf], Review of Dudley Tyng, Massachusetts Reports (1817), 7 N. AM. REV. \& MiSC. J. 184,188 (1818).

${ }^{99}$ Id. at 194 ("Some [reporters] would wholly exclude the arguments of counsel — and some would have them stated at great length. Some would have a full copy of the pleadings, and make our reports... a book of entries, as well as decisions. Others wish for nothing but the mere point decided....").

${ }^{100} \mathrm{Id}$. at 194. 
opinions, without which "it is impossible for the most scrupulously careful reporter always to state [an opinion] correctly." 101

Wheaton's 1819 review of Justice Story's opinions for the United States First Circuit praised the learning displayed in the opinions, and congratulated reporter William Mason for limiting his own contributions to recording the opinions and arguments of counsel. ${ }^{102}$ In 1820, Story published a praiseful review of the first three volumes of James Kent's New York Court of Chancery opinions, which acknowledged reporter William Johnson for his work reporting the chancery decisions and New York Supreme Court opinions, which "will bear comparison with those of an equal period of the best age of the English law." 103

In 1824 Caleb Cushing reviewed the final volumes of Johnson's New York cases and Tyng's Massachusetts cases, as well as Wheaton's eighth volume of Supreme Court reports. ${ }^{104}$ Cushing noted that New York and Massachusetts were the first states to appoint official reporters, which had helped make decisions from their courts nationally influential. Johnson and Tyng "had each reported a larger number of cases than any other American author," and each pursued "decidedly the best" method of reporting: "to give a succinct statement of facts agreed or stated in pleading, the points made and authorities cited at the bar, and the opinion of the court at full length."105

In an 1825 review of Octavius Pickering's first volume of Massachusetts Reports, Willard Phillips argued for requiring judges to prepare and sign written opinions, which would allow the reporter to concentrate on making "a good selection of cases ... and to present perspicuous and satisfactory statements of the facts and the arguments of counsel," something that "requires not a little talent, discrimination, labor, legal science and skill."106 To Phillips, including arguments was of great importance because it made a court justify its decision and threw more light on the decision than might be provided by the opinion alone. ${ }^{107}$

${ }^{101} I d$. at $195-96$.

102 [Henry Wheaton], Review of William P. Mason, U.S. First Circuit Reports (1819), 8 N. AM. REV. \& MiSC. J. 253, 254 (1819).

103 [Joseph Story], Review of William Johnson, New York Chancery Reports (1816, 1818, 1819), 11 N. AM. REV. \&

MisC. J. 140, 165 (1820). Story wrote that Johnson "loves the law with all his heart, and has a sincere and

unaffected enthusiasm for its advancement. $I d$. at 164.

The review prompted Kent to initiate an exchange of letters with Story. See 1 LIFE AND LETTERS OF JOSEPH STORY 377-380 (William W. Story, ed. 1851). Perry Miller suggests that the review "was discussed throughout the nation." MiLLER, supra note 38 at 174.

${ }^{104}$ Review of Wheaton's, Johnson's and Tyng's Reports, supra note 96 at 374.

105 Id. at 375 .

106 [Willard Phillips], Review of Octavius Pickering, Massachusetts Reports (1823), 20 N. AM. REV. 186 (1825). For Phillips, "publication of a third, or half, or at most two thirds of the cases argued and determined, is quite as useful as to publish the whole number." Id. at 186.

${ }^{107}$ Id. at 188 .

In an 1826 review of the second volume of Simon Greenleaf's Maine Reports Nathaniel Haven described Greenleaf as an accomplished reporter who exhibited "legal penetration and acumen, as well as a familiarity with principles and forms, and an adroitness in reference and application." Although he quibbled with the extent to which Greenleaf occasionally compressed arguments of counsel, Haven placed Greenleaf within "the order of compendious reporters." [Nathaniel Haven], Review of Simon Greenleaf, Maine Reports (1824), 22 N. AM. REV. 27, 30, (1826).

William Howard Gardiner's 1826 review of Pickering's third volume welcomed the reporter's innovation of "promulgating [decisions] from time to time in the shape of a well-sized pamphlet, instead of waiting for the tardy 


\section{Other Topics}

Reviews published in the North American Review and other periodicals prior to 1830 commented not only on the quality of the reporter's efforts, but on the value of published reports, the issues raised by the growing numbers of published opinions, and other topics connected to their publication. In his review of Wheaton's first volume of Supreme Court opinions, John Gallison noted the importance of developing uniformity in national law ${ }^{108}$ and the role of published reports in keeping the courts within proper bounds. ${ }^{109}$ The Literary Gazette began a review of Thomas Sergeant's and William Rawle's Pennsylvania Reports by noting the importance of publishing opinions, and arguing for the appointment of official reporters in every state. ${ }^{110}$ In his review of Wheaton's seventh volume of Supreme Court Reports, Theron Metcalf praised the work of the Supreme Court compared to the state courts, ${ }^{111}$ finding it scandalous that the Court's decisions had such limited circulation among lawyers, politicians, and scholars. ${ }^{112}$

Concerns about the complexity and inaccessibility of statutory and case law were common in the first years of the nineteenth century. The states typically attempted to deal with the problems through statutory revision ${ }^{113}$ or by improving their systems for reporting decisions. ${ }^{114}$ In 1817 Joseph Story complemented David Hoffman for recommending "full and careful study of the .. civil law" to law students in his Course of Legal Study. ${ }^{115}$ With some support from prominent Americans, Jeremy Bentham himself wrote to President Madison and to state governors, offering to draft codes for the United States and individual states. ${ }^{116}$ New Hampshire's governor presented Bentham's proposal to the state legislature in June 1818. Although not acted upon, ${ }^{117}$ the proposal provoked criticisms of codification in the journals.

In a July review of Massachusetts cases Theron Metcalf praised the common law and expressed "disgust and indignation" for those who reviled it in favor of codification, ${ }^{118}$ asserting "that no

accumulation of a whole volume." [William Howard Gardiner], Review of Octavius Pickering, Massachusetts Reports (1826), 23 N. AM. REV. 217, 217 (1826). Gardiner reviewed the first pamphlet of the volume.

108 [Gallison], Review of Wheaton's Reports (1816), supra note 90 at 111.

${ }^{109} \mathrm{Id}$. at 112.

${ }^{110}$ Review of Thomas Sergeant and William Rawle, Pennsylvania Reports (1818, 1820), Literary Gazette, Jan. 6, 1821, at 1, 2. The review erroneously stated that Dallas's Reports were "the first publication of Reported Cases in the United States." Id.

111 [Metcalf], Review of Wheaton's Reports (1822), supra note 96 at 119 ("the prospects of legal science are, at this hour, in every state north of Pennsylvania, worse than they have been at a former period.”).

${ }^{112} I d$. at 128

${ }^{113}$ Charles M. Cook, The American Codification Movement 24-29 (1981). Cook's book remains the standard study of nineteenth century American codification. It should be read in conjunction with Robert W. Gordon, Book

Review, 36 Vanderbilt L. Rev. 431 (1983) and Andrew J. King, Book Review, 41 Md. L. Rev. 329 (1982).

114 See Cook, supra note 113 at 29-32 ("Of course, the layman who complained of the complexity of the law found little solace or assistance in published opinions." Id. at 32).

115 [Joseph Story], A Course of Legal Study Respectfully Addressed to the Students of Law in the United States by David Hoffman, 6 North-American Rev. \& Misc. J. 45, 76 (1817) (book review). There was also enough interest in the civil law for the American Law Journal to publish translations of several codes. See Cook, supra note 113 at $96-$ 7.

${ }^{116}$ Cook, supra note 113 at 97-102.

117 The New Hampshire legislature did not act on the proposal, postponing it to the following year's session where it was not taken up. Id. at 101-02.

118 [Metcalf], Review of Tyng's Massachusetts Reports (1817), supra note 98 at 185. 
honest man, who understands the common law as a system, will vilify it in the style we have noticed." 119 Against complaints about the growing number of cases, he noted that the volume of reports should be expected to grow because "there will never be an end of new questions." 120 In the same month, a Port-Folio review ${ }^{121}$ criticized civil law systems for relying on learned treatises rather than reported cases, arguing that because treatises lacked the authority of judicial decisions they failed to create certainty and stability. ${ }^{122}$ Daniel Webster opened his review of Wheaton's reports by denouncing advocates of codification for suggesting the possibility that positive enactments could provide for all questions that would arise in future. ${ }^{123}$

Webster described the eagerness with which lawyers now read "the multitude of reported decisions," as "the highest evidence of our enlightened and civilized state."124 In his 1821 address to the Suffolk Bar, Joseph Story worried about the effects of the growing "mass of the law" on students and professors, ${ }^{125}$ but also cited the then-150 published volumes of American reports as evidence of: "uncommon devotion to the study of the law, and uncommon ambition to acquire the highest professional character." 126 In 1822, in his review of Greenleaf's A Collection of Cases Overruled, Doubted, or Limited in Their Application, Metcalf noted that the 600 cases Greenleaf included might well have been a thousand, but even that number was small in light of the number of volumes of reports that had been published in common law countries, even during the short history of the United States. ${ }^{127}$ Metcalf noted particularly the inevitability of "contradictory judgments by the courts of the different states." 128

In a December 1823 address to the Historical Society of New York on "the origin, progress, antiquities, curiosities, and nature of the Common Law," William Sampson argued that the common law system was inappropriate for the United States and should be replaced with codification. ${ }^{129}$ Sampson's Discourse was published during a time when there were no regularly published journals devoted solely to law. ${ }^{130}$ Commentary and further discussion of the speech,

${ }^{119}$ Id. at 186.

${ }^{120} \mathrm{Id}$. at $184,187$.

${ }^{121}$ Review of Jasper Yeates, Pennsylvania Reports (1817-18), 6 Port-Folio 50 (1818). The review noted that it had been written for publication in John Hall's American Law Journal, and asked that readers holding manuscripts of unpublished decisions forward them to Hall for publication. Id. at 54.

${ }^{122} \mathrm{Id}$. at 50-51. The reviewer also commented on Yeates's work in comparison to that of Dallas, whose reports of Pennsylvania cases covered part of the same period. Each included cases not found in the other; those included by both were "in most cases, less full and circumstantial" in Dallas. Id. at 53.

${ }^{123}$ [Webster] Review of Wheaton's U.S. Reports (1818), supra note 95 at 63. Because the legislature can only establish principles, their "combination, modification, and application ... must be left to those who administer the laws." Id. at 64.

${ }^{124} \mathrm{Id}$. at 67.

125 Story, Suffolk Address, supra note 3 at 31. Andrew King wrote that that between " $1815-1850$, an increasing number of reported cases and an eruption of new case lase doctrine produced an information overload for the legal profession." King, supra note 113 at 332.

${ }^{126}$ Story, Suffolk Address, supra note 3 at 13.

${ }^{127}$ [Metcalf], Review of Greenleaf's Collection of Cases, supra note 97 at 65.

${ }^{128} I d$. at 68 .

129 WiLliam SAMPSON, AN ANNIVERSARY DisCOURSE DELIVERED BEFORE THE HiSTORICAL SOCIETY (1824).

130 The United States Law Journal, infra text accompanying notes 171-82, published four issues in 1822-1823 and another two in 1826, but made only brief references to codification, one in a review describing an unnamed author as "fearing to declare himself openly as an advocate for codification, yet he cannot avoid the strong and peculiar cant of his sect." See Review of Samuel Hopkins, New York Chancery Reports, 2 U.S. L.J. 282, 289 (1826). 
often via reviews of new reports, were published in the North American Review and other literary journals. ${ }^{131}$

The short-lived Atlantic Magazine (1824-1825) published a critical review in its first issue, noting that although it did not intend to cover "subjects of an exclusively professional character; ... the common law is a matter of general concern." ${ }^{\prime 32}$ The review was soon followed by a lengthy article arguing against replacement of the common law by codes, which pointed out that the common law formed one of the strongest bonds among the states. ${ }^{133}$ In April 1824 the Port-Folio included examples of Sampson's prose in a review of the published version of the speech, but closed with a quotation from Joseph Hopkinson's 1809 defense of the common law. ${ }^{134}$

In October 1824, the North American Review published a supportive 28-page review of Sampson's Discourse by attorney Henry Dwight Sedgwick. ${ }^{135}$ Perry Miller later called Sedgwick's comments "judicious," a characteristic "not thereafter, on this topic, to distinguish that patrician journal." "136 Sedgwick may have been judicious, but he was not neutral on the subjects of the common law and codification. In 1822, as "A Lover of Improvement," he published a short book aimed at "Showing Some of the Evils and Absurdities of the Practice of the English Common Law as Adopted in Several of the United States." 137 When Sampson published a signed review article

${ }^{131}$ See Maxwell Bloomfield, William Sampson and Codifiers: The Roots of American Legal Reform, $1820-1830,11$ AM. J. LEGAL HIST. 234, 243 (1967). Robert Gordon writes that the debates over codification were overwhelmingly a preoccupation of ... a small elite of academically minded lawyers" and that "the vast literature on the subject consists largely of anthems raised to the common law." Gordon, supra note 113 at 434 . Bloomfield found that "Sampson and his adherents ... worked for reform within the legal profession, looking to the scholar rather the demagogue to carry through their program.” Bloomfield, supra at 242 (1967). For a succinct description of codification discussions in the 1820s and after, see KUNAL M. PARKER, COMMON LAW, HiSTORY, AND DEMOCRACY IN AMERICA, 1790-1900 at 124-26. (2011). For discussion of the articles published in the North American Review, see STEIN, supra note 84 at 415-22.

132 The Common Law, 1 Atlantic Mag. 23, 29 (1824). The Atlantic Magazine was founded by lawyer Robert C. Sands. 1 MOTT, supra note 18 at 334.

${ }^{133}$ On the Substitution of a Written Code, in the Place of the Common Law, 1 ATLANTIC MaG. 283, 296 (1824).

134 The Common Law, PORT-FOLIO, April 1924, at 296, 298-99, quoting JOSEPH HoPKINSON, CONSIDERATIONS ON THE ABOLITION OF THE COMMON LAW IN THE UNITED STATES (1809).

135 [Henry Dwight Sedgwick], Review of William Sampson, An Anniversary Discourse Delivered before the Historical Society (1824), 18 N. AM. REV. 411 (1824) (book review). Two years later Sedgwick reviewed an enlarged edition of Sampson's Discourse with additional correspondence and commentary. See [Henry Dwight Sedgwick], Sampson's Discourse and Correspondence with Various Learned Jurists upon the History of the Law, with the Addition of Several Essays, Tracts, and Documents Relating to the Subject by Pishey Thompson, 23 N. AM. REV. 197 (1826) (book review).

${ }^{136}$ MILLER, supra note 38 at 249 (1965) ("In the early 1820's codification could still be discussed without hysteria." Id.). In an 1827 review, W.H. Gardiner noted that the North American Review could not "pretend to much consistency in our own pages upon this topic, having already found occasion ... to argue both sides of the case, before the question is well-settled." [W.H. Gardiner], Review of Report from the Commissioners Appointed to Revise the Statute Laws of the State of New York, 24 N. AM. REV. 193, 193 (1827).

For positive comments on the civil law in the North American Review, see [Joseph Story], Review of Nathan Dane, A General Abridgment and Digest of American Law (1823-1824) 23 N. AM. REV. 1 (1826); [Charles Everett], Review of Proceedings and Report of the Commissioners for the University of Virginia (1818), 10 N. AM. REV. \& Misc. J. 115 (1820); [Caleb Cushing], On the Study of the Civil Law, 11 N. AM. REV. \& MiSC. J. 407 (1820); [Henry Wheaton], Review of Robert Pothier, A Treatise on Maritime Contracts of Letting to Hire, 13 N. AM. REV. 1 (1821).

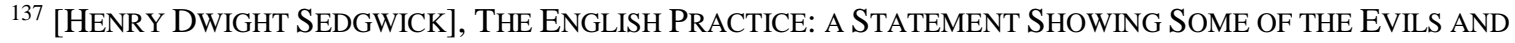
ABSURdities OF THE PRACTICE OF THE ENGLISH COMMON LAW AS ADOPTED IN SEVERAL OF THE UNITED STATES AND PARTICULARLY IN THE STATE OF NEW YORK (1822). 
in the Atlantic Magazine in 1825 pointing out the abuses of the common law, he strongly recommended Sedgwick's book as a source where "many practical abuses very easy to be remedied, are pointed out with candor and precision." 138

Advocates of codification often focused on what Caleb Cushing called "the vast and increasing multiplication of reports" in his April 1824 review of reports issued by Wheaton, Johnson, and Tyng. ${ }^{139}$ Cushing praised the reporters' efforts, but asked:

Whither is this rapid increase of reports to lead us, and what are to be the end and consequences of it? If year after year is be thus prolific of its annual harvest of reports, we do not ask what fortunes will ere long be capable of compassing the purchase of a complete law library, but we ask what mind will be adequate to the task of storing up the infinite multiplicity of decided cases? ${ }^{140}$

The review found "[t]he vast and increasing multiplication of reports, as well as law treatises," to be "a very remarkable fact in our legal history [and] a standing subject of complaint these many years." ${ }^{141}$ Cushing feared for the future. To lessen the need to pour through so many volumes, he proposed not codification, but publication of new editions of the older English Reports, edited to remove obsolete cases, with the remaining cases enhanced with references and annotations to show their present applicability. ${ }^{142}$

In its 1825 review of Greenleaf's Maine Reports, the United States Literary Gazette (18241826) lamented the frequency with which new volumes of reports appeared, attributing the growing numbers to "sectional pride and ambition, professed by a majority of the states, to preserve the decisions of their tribunals," as well as to the sense of "learned and industrious minds" that applications of legal principles "should be seen in extenso in order to be better understood and better appreciated." 143 Haven's 1826 review of Greenleaf's Reports pointed out that prior to 1800 "[t]he best library of American reports that could be summoned by money or magic ... might have been borne [in] the circuits in a portfolio." Nonetheless, he stressed the value of the reports themselves as "vehicles of decisions, interesting and important in public estimation," through which "the principles of the common law are becoming every day ... better understood, and our judicial character more effectually established." 144

Willard Phillips's 1825 review of Pickering's first volume of Massachusetts Reports argued that should be no objections to publishing the reports, regardless of one's position on codification. The knowledge that their work will be publicly available and scrutinized improved the quality of the work of both advocates and judges. ${ }^{145}$ He found it remarkable that some states had not

138 William Sampson, [Review], 2 Atlantic MAG. 281, 292 (1825).

${ }^{139}$ [Cushing], Review of Wheaton's, Johnson's and Tyng's Reports, supra note 96 at 375.

140 Id. at 377

${ }^{141} I d$. at 375 .

${ }^{142} I d$. at 381.

${ }^{143}$ Review of Simon Greenleaf, Maine Reports (1824), 2 U.S. LITERARY GAZETTE 463, 463 (1825).

144 [Haven], Review of Greenleaf's Maine Reports (1824), supra note 107 at 29.

145 [Phillips], Review of Pickering's Massachusetts Reports (1823), supra note 106 at 182 ("The practice of reporting decisions, with their grounds and reasons, is indeed an insuperable barrier to the corruption of judges [and] the strongest possible guard against negligent and inconsiderate decrees."). 
appointed official reporters, finding unofficial reporting to be "a very precarious way of supplying the community with the means of knowing by what laws and rules of conduct they are governed." 146

In a 1828 review of Second Circuit cases consisting mostly of a defense of the common law, Jonathan Porter noted complaints about "the great number and of the rapid multiplication of law reports," but argued that because "publication of such reports is the promulgation of the laws ... no other way is ... possible to make them generally known." Although law books are "expensive to purchase, and laborious to read.... this is a difficulty attending the advancement of all the sciences... the man of real science does not very often complain of the multiplication of books upon his favorite theme." And, as in any science, it was not necessary to read every published reports. Case digests relieved lawyers of that burden. ${ }^{147}$

Anticipating the pedagogy of Christopher C. Langdell, Porter also expressed a wish "to see some books of reports put earlier into the hands of youth for their legal education, than they have been hitherto." With proper introduction, students would find the reports "far more interesting and instructive to read, and infinitely more easy [sic] to remember, than codes, digests, or elementary treatises." 148 Most importantly, reading cases would improve understanding and retention of legal principles: "The facts in the cases serve as bonds of association, by which the principles interwoven with them are held together, and kept long and strongly fastened in the mind."149

By the 1830s, when specialized legal journals became more readily available, general periodicals reviewed new volumes of reports less frequently. ${ }^{150}$ The North American Review stopped reviewing Wheaton's U.S. Supreme Court Reports after his eighth volume in 1824. Richard Peters succeeded Wheaton as Supreme Court Reporter in 1828, continuing until 1843, but only his eleventh volume, for the 1837 term, was reviewed. Maine attorney Charles Stewart Daveis criticized Peters for not confining his notes to points actually decided by the Court, but quoting dicta and other comments from the opinions at length. Daveis inferred from this practice "that there is nothing strictly extrajudicial understood by [Peters] to be contained in the opinion

${ }^{146} I d$. at 183 (1825). Phillips noted in passing the "loud calls from many quarters for codes and abridgements" from lawyers wishing to contend with fewer books and others wishing that the law might "be so abridged, simplified, and elucidated, that every boy leaving the public schools should be a good practicing attorney...." Id. at 181 .

Later that year, William Howard Gardiner's brief review of the first part of a new volume of Pickering's Reports highlighted the reporter's plan to publish recent decisions in pamphlet form, "instead of waiting for the tardy accumulation of a whole volume." Gardiner pointed out the importance of quick dissemination of new decisions to practitioners and their clients, who "might have been saved the expense and vexation of a suit instituted and resisted for the purpose of ascertaining some point of glorious uncertainty in the law," which had recently been settled in another jurisdiction." [William Howard Gardiner], Review of Octavius Pickering, Massachusetts Reports (1826), 23 N. AM. REV. 217, 217 (1826).

${ }^{147}$ [Jonathan Porter], Review of Elijah Paine, U.S. Second Circuit Reports (1827), 27 N. AM. REV. 167, 179 (1828).

148 Id. at 181

${ }^{149} I d$. at $181-82$

${ }^{150}$ See, e.g., Review of Hiram Denio, New York Reports (1849), 4 LITERARY WORLD 221 (1849); Review of Daniel Call, Virginia Reports (1854), 20 SO. LITERARY MESSENGER 508 (1854); Review of John Patton \& Roscoe Heath, Virginia Special Court of Appeals Reports (1856), 22 SO. LITERARY MESSENGER 399 (1856). 
pronounced in the name of the Court." ${ }^{151}$ No reviews of new volumes of state reports were published in the Review after 1828.

\section{Reviews in the First Legal Periodicals}

In a paper offered at the 1928 meeting of the Association of American Law Schools, Roscoe Pound identified three types of legal periodicals: the purely academic type characteristically found in Continental legal systems; the purely professional type published in England; and a "mixed, or academic-professional type," in the United States. ${ }^{152}$ While Pound's sense of American legal periodicals as a mix of the academic and professional was probably accurate when he spoke, it was so only since the start of the Harvard Law Review in $1887 .{ }^{153}$ For much of the nineteenth century, American legal periodicals, like those in England, were aimed at the needs of practitioners rather than of scholars. ${ }^{154}$ Pound himself described the legal environment of the early nineteenth century a one in which the legal profession "was neither organized nor specialized"; the practice of law was decentralized, consisting of "local groups or aggregates of unorganised practicing lawyers"; and the states controlled the details of the law, fostering a "tendency toward a minute development of local law and local procedure." 155 The result was an increasingly "disjointed body of common law ... there were so many cases being decided in so many jurisdictions that one could hardly keep up. Moreover, the reporters rarely analyzed or commented upon these cases." 156 In addition, the available treatises were usually national in scope, and did not meet all the needs of practitioners whose practices were mostly based in local or state law." 157

As a result, lawyers relied on professional journals to find important new decisions, often being the first, and sometimes the only, places that some cases could be found." 158 The new journals usually also included some "biographical and statistical material, questions of legal reform, chitchat, and gossip, and [even] an enlivening anecdote" ${ }^{\prime 159}$; content similar to that of the new specialized magazines developing in other fields.

151 [Charles Stewart Daveis], Review of Richard Peters, U.S. Reports (1837), 46 N. AM. REV.126, 152 (1838). In 1857, Timothy Farrar discussed the Dred Scott decision under a citation to Benjamin Howard's Reports, but did not mention the reporter. [Timothy Farrar], A Report of the Decision of the Supreme Court of the United States, 85 N. AM. REV. 392 (1857). In 1861, Joel Parker published a lengthy comment on habeas corpus and martial law under the title of Chief Justice Taney's opinion in the Case of John Merryman. [Joel Parker],Opinion of Chief Justice Taney, in the Case of John Merryman, Applicant for a Writ of Habeas Corpus, 93 N. AM. REV.471 (1861).

152 Roscoe Pound, Types of Legal Periodical, 14 Iowa L. Rev. 257, 257 (1929).

${ }^{153}$ For the origins of the Harvard Law Review, as well as the history of earlier attempts to publish journals at the Albany and Columbia law schools, see Swygert \& Bruce, supra note 18 at 763-78.

154 Berring notes that the student-edited law reviews initially saw themselves not as competitors to the commercial journals, but were aimed instead at alumni of the schools or local audiences. Berring, History and Development, supra note 18 at 6-7. See also The Harvard Law Review, 15 AM. L. REC. 689, 689 (1887).

155 Pound, supra note 152 at 262.

156 Swygert \& Bruce, supra note 18 at 751.

157 See Richard A. Danner, Oh, The Treatise, 111 MicH. L. REV. 824-828 (2013).

${ }^{158}$ Berring, History and Development, supra note 18 at 6. But see Current Topics, 11 ALB. L.J. 1, 1 (1875) ("Many of [the early periodicals] have been only reports of decisions under another name, and VERY poor reports at that.").

159 See American Law Periodicals, supra note 18 at 445. 
Lawyers' needs for access to cases and other materials of local interest created potential markets for new journals, but it was difficult for attempts at national legal periodicals to succeed. ${ }^{160}$ In addition to problems of financial support (which also plagued early specialized periodicals in other fields), many of the early law journals failed "because they were too similar to law reports, too local in flavor, too broadly focused, or too technical.",161

\section{The American Law Journal and Miscellaneous Repertory}

The earliest American law periodical, the American Law Journal and Miscellaneous Repertory, began publication in 1808, under the editorship of John E. Hall, ${ }^{162}$ who modeled his effort on the London-based Law Journal (1804-1806): the London Law Journal's "frequent recurrence of publication enabled the editors to give the earliest intelligence of new and important decisions on points in which the commercial world was deeply interested [and] offered a fair opportunity to professional gentlemen, to prosecute their researches by anonymous communications." 163 The American Law Journal mostly published recent cases, but also included short biographies, commentary, and notes on cases and new books: two of reports, both reprinted from The Monthly Anthology, and Boston Review. ${ }^{164}$

160 "It was not until the fifth decade of the nineteenth century that national legal periodicals were able to take root." Pound, supra note 152 at 262-263.

${ }^{161}$ Swygert \& Bruce, supra note 18 at 753-54. In an 1870 review and history of American legal periodicals, the Albany Law Journal blamed the "[1]ack of tact and energy on the part of publishers" for the failures of early journals. American Law Periodicals, supra note 18 at 445.

${ }^{162}$ Hall was a contributor to and sometime editor of Port Folio. 1 MotT, supra note 18 at 154 . For information on his life and career, see Maxwell Bloomfield, Hall, John Elihu, 9 AMERICAN NATIONAL BIOGRAPHY 863 (1999). See also Zoey F. Orol, Note, Reading the Early American Legal Profession: A Study of the First American Law Review, 87 N.Y.U. L. REV. 1523, 1529-33, 1559-61 (2012) ( discussing the American Law Journal's selection of cases and laws). In 1870 the Albany Law Journal found however that "one looks almost in vain for the miscellany which the Repository promises." American Law Periodicals, supra note 18 at 445.

${ }^{163}$ Preface, 1 AM. L.J. \& MisC. REPERTORY v, v (1808).

Anonymous publishing typified early journals in all fields. One early history of nineteenth century periodicals suggests that "[m]ost periodicals and even some writers were eager to demonstrate that art should be its own reward." TASSIN, supra note 87 at 312. John Tebbel suggests that "Since writing for [magazine] publication was considered not quite respectable, articles were mostly unsigned or pseudonyms were used." JOHN TEBBEL, THE AMERICAN MAGAZINE: A COMPACT HISTORY 28 (1969). Tassin reports that Henry Wadsworth Longfellow "more than once wrote to a periodical that he would contribute if only he could do so anonymously." TASSIN, supra note 87 at 3.

In the $1820 \mathrm{~s}$ " $[\mathrm{t}] \mathrm{he}$ practice of anonymity was still very general, especially in the more dignified magazines. The reviews seldom broke over into what they deemed vulgar signing of articles...But more and more the signing custom grew...." 1 MOTT, supra note 18 at 503. Yet, although "some of the most important American monthlies and quarterlies preserved the custom of anonymity" in published issues, their editors sometimes inserted slips with the names of contributors in copies sent to newspapers. 2 MOTT, supra note 18 at 25-26.

In 1838, the editors of the American Jurist and Law Magazine announced that they would publish authors' initials with their articles. See On the Plans and Objects of the American Jurist and Law Magazine, 19 AM. JURIST \& L. MAG. 1, 7 (1838). In 1843, the editor of the Western Law Journal (1843-1853) wrote that he "wished to make it distinctly understood, that no article will be published anonymously. Every contributor must take the responsibility of what he furnishes, be it for praise or censure." T. Walker, Prospectus of the Western Law Journal, 1 WESTERN L.J. 1, 2 (1843). The Albany Law Journal later credited Walker with the innovation "requiring a writer to append his name to his productions." American Law Periodicals, supra note 18 at 447. For criticism of the Western Law Journal practice, see American Law Journals, 7 LAW REP. 66, 73 (1844).

${ }^{164}$ One was of Tyng's first volume of Massachusetts Reports, Review of Tyng's Massachusetts Reports (1806), supra note 52; the other of Thomas Day's edition of English nisi prisi cases, Review of Thomas Day, Reports of 
In 1809, The Monthly Anthology called publications like Hall's "absolutely necessary" for showing differences among state laws and fostering uniformity on questions of commercial law, ${ }^{165}$ In 1815, the Port-Folio noted the Journal's "well merited and increasing reputation" and expressed confidence that "the science of law would be materially benefited in the United States' were it widely circulated." 166 Yet, by 1817 the American Law Journal had ceased publication.

In 1821 Hall started The Journal of Jurisprudence (1821) as a "New Series" of the American Law Journal. ${ }^{167}$ The first issue, reprinted favorable notices from several newspapers: one pointing out the Journal's superiority to English legal journals; others emphasizing its role in promoting uniformity in American law. ${ }^{168}$ Peter du Ponceau wrote that law journals "offer[ed] a better and perhaps, the only rational and constitutional mode of obviating the difficulty which results from the difference of state laws." "169 The Journal of Jurisprudence published three issues before stopping publication.

Other legal journals started before 1820 included: the semi-annual Carolina Law Repository (1813-1818) which published cases from North Carolina, digests of cases from other jurisdictions, short biographies, and commentary (some by non-lawyers) ${ }^{170}$; the weekly Examiner [New York] (1813-1816), which focused on political topics but included the texts of occasional statutes; and two monthlies: the New York City Hall Recorder (1816-1822); and the New York Judicial Repository (1818-1819), each of which published only cases and trial transcripts.

\section{The United States Law Journal}

The United States Law Journal issued one volume in 1822-1823, and another under new editors in $1826 .{ }^{171}$ In several reviews of reports from New York courts, the Journal concentrated on the quality of the reporter's efforts, the amount of questionable material included in the volumes, and the growing number of reports being published. An 1822 review of John Anthon's reports of New York nisi prius cases took the reviewer "back to the good old days, when ... long speeches of counsel, figures of rhetoric, and wide margins, were not the ruling passions of the age.

Cases argued and ruled at Nisi Prius, 5 Monthly Anthology, And Boston ReV. 588 (1808). For the reprints, see Review of Dudley Tyng, Massachusetts Reports (1806), 3 AM. L.J. \& MISC. REPERTORY 361 (1808); Review of Thomas Day, Reports of Nisi Prius Cases, 2 AM. L.J. \& MiSC. REPERTORY 173 (1809).

165 Intelligence and Miscellaneous Articles: Domestick, MonTHLY ANTHOLOGY, AND Boston REV., June 1, 1809, at 428, 428. It also chastened him for publishing a case already available elsewhere. Id. at 429.

166 Hall's American Law Journal, 5 PORT-FOLIO 190, 190 (1815).

167 See G.G. [George Gibbs], Digests, supra note 8 at 135. See also Joel Fishman, Another Early Pennsylvania Legal Periodical: Journal of Jurisprudence (1821), 3 UnBOUND 61 (2010) (discussing the Journal's publication history and content).

168 Testimon. Erudite. Biror. 1 J. JURISPRUDENCE 3 (1821).

${ }^{169}$ Peter S. du Ponceau, 1 J. JURISPRUDENCE 3, 4 (1821) reprinted from Freeman's Journal (Phil.).

${ }^{170}$ North Carolina cases published in the Repository were later incorporated into volume 4 of North Carolina Reports. See SURRENCY, supra note 18 at 189 (1990). See generally American Legal Periodicals, supra note 18 at 446.

${ }^{171}$ The first issue was published as the United States Law Journal and Civilian's Magazine. See [Caleb Cushing], United States Law Journal and Civilian's Magazine, 16 NoRTH AM. REV. 181 (1823). See generally Simeon E. Baldwin, The United States Law Journal of 1822, 4 A.B.A. J. 37 (1918). 
It calls to mind the days when Judges expounded the law in sound terms, and in the language of luminous simplicity." The reports provided a model for "brevity and compression.".172

Later that year the Journal took a harsher view of William Johnson's New York Supreme Court Reports. Noting Johnson's advantages as an officially-appointed reporter, the reviewer found that: "We do not know that we have any sufficient reason to accuse him of direct bookmaking: we will not say that he has designedly swelled the bulk and number of his volumes merely for the sake of gain." Nonetheless, "[t]he instances are frequent in which there is nothing new in the principle of the decision; and there are many other instances where the point determined, is of an entirely local, private, or transitory nature." 173 The reviewer acknowledged that Johnson was not alone in his transgressions: "the rage for reporting is really getting to be a mania. ...It will by and by be the work of a lifetime to learn even the name of these reporters." 174

Johnson was succeeded as New York Supreme Court reporter in 1923 by Esek Cowen, whose first four volumes were reviewed by the U.S. Law Journal in 1826. Cowen's reviewer acknowledged that Johnson had been treated "with a good deal of freedom," but found Cowen to be "chargeable, in a much greater and more grievous degree." His first volume included practice cases "destitute of all claims to the attention of the reader, and no small number are really frivolous." ${ }^{175}$ Despite claiming to value brevity: "Mr. Cowen [like Johnson], finds the mechanical labour of copying cases, and special verdicts, and pleadings, \&c. much easier, as well as more profitable, than the intellectual exertion of making abstracts of their most material parts." 176 The review concluded that "Cowen goes entirely beyond [Johnson] in every thing that is reprehensible, and we cannot discover that he has improved upon him in a single particular."177

In its final issue, the Journal revisited its comments on Johnson and Cowen in a review of Samuel Hopkins's Reports of New York chancery decisions, suggesting that while the review of Johnson's Reports might have been personally unpleasant to him, it had provided "fair and candid criticism." "178 Had Johnson's reporting style been more concise, Cowen's Reports might “not have extended them as he has done and is now doing." 179 Of Hopkins's Reports, the reviewer could "speak only in terms of decided commendation." 180 At his rate of reporting, Hopkins would "not add to our libraries more than a volume in three years; and we can well afford to purchase his

172 Review of [John] Anthon's Nisi Prius: The Law of Nisi Prius (1820), 1 U.S. L.J. 106, 107-08 (1822).

${ }^{173}$ Review of William Johnson, New York Reports (1821-1822), 1 U.S. L.J. 174, 210 (1822)

${ }^{174}$ Id. at 213. See also Review of Anthon's Reports, supra note 172 at 108 ("Reporters of legal decisions should be the last people to resort to book-making.").

${ }^{175}$ Review of Esek Cowen, New York Reports (1823-1825), 2 U.S. L.J. 1, 1, 2 (1826).

${ }^{176} I d$. at 4. Noting that the judges prepared their own written opinions for publication, Cowen's reviewer wondered whether they mandated the reporter to print the opinions in their entirety, then questioned the usefulness of requiring written opinions if it created additional burdens for the court to produce and resulted in delay. Id. at 6-8.

${ }^{177}$ Id. at 49.

Mr. Cowen seems to be under the influence of a kind of half-formed and ill-defined expectation, that in process of time, by reporting every thing, the whole law will become embodied in his works, and that all other repositories of legal knowledge will fall into disuse. ... [W] think there is a great deal of the same scheme visible in the reports of Mr. Johnson. That gentleman, however, does not seem to have carried the idea quite as far as Mr. Cowen, though perhaps, every thing considered, he is more to blame for having set the example.

Id.

${ }^{178}$ Review of Hopkins's New York Chancery Reports (1826), 2 U.S. L.J. 282, 289 (1826).

${ }^{179} I d$. at 291.

${ }^{180} I d$. at 282 . 
works and to peruse them... [H]ad he no other merit, he is likely to be the most valuable reporter we have ever had." 181 The reviewer also questioned the benefits of requirements for written opinions, pointing out the "proneness in all men when the pen is once in hand ... to say more than the occasion requires." Although the rapid accumulation of published reports was caused in part by the insertion of unnecessary cases and the failure of reporters to condense statements of facts and arguments of counsel, "the main cause unquestionably is the length of the opinions delivered from the bench." 182

\section{The American Jurist and Law Magazine}

Two legal journals began publication in $1829 .{ }^{183}$ The United States Law Intelligencer and Review completed three volumes before ending in 1831; the American Jurist and Law Magazine continued until 1843. In its prospectus, the Law Intelligencer noted that law lacked "regular journals of the discoveries and improvements which result from experiment, investigation and time," and that there was room in law for journals of different sorts. The Intelligencer itself planned to be "a synopsis or abridged record of the changes and progress of the Law," and saw the American Jurist as likely to "be confined almost exclusively to the discussion of general topics, which, however interesting to the Lawyer, are not immediately connected with his wants and practice." "184 1870 the Albany Law Journal characterized the Intelligencer and Review as the "first publication displaying the distinctive features of the law magazine as it to-day exists." 185 Swygert and Bruce note that it was the first to publish lead articles. ${ }^{186}$

The American Jurist was the first legal journal to last more than a few volumes until the Law Reporter in 1838. A later reviewer called it the "first compact, methodical and comprehensive law periodical" published in America. ${ }^{187}$ Notably, in its first issue, the Jurist published Joseph Story's 1821 address to the Suffolk Bar Association. ${ }^{188}$

${ }^{181} I d$. at 284.

${ }^{182} \mathrm{Id}$. at 285. For a twentieth-century argument against requiring written opinions see Max Radin, The Requirement of Written Opinions, 18 CAL. L. REV. 486, 491 (1930) (discussing California's constitutional requirement for written opinions in historical and national contexts).

${ }^{183}$ Other legal journals started in the 1820s include the Annual Law Register of the United States (1822), an attempt to compile selected state statutes that failed after two issues; and the Journal of the Law-School, and of the Moot-

Court Attached to It, which documented the moot court activities of the law school at Needham, Virginia (1822). The American Jurist found the Law Register to have a "far more accurate and complete American legal bibliography than had before been published." G.G. [George Gibbs], Digests, supra note 8 at 136. See also American Law Periodicals, supra note 18 at 446.

${ }^{184}$ Proposals for the United States Law Intelligencer, 1 U.S. L. INTELLIGENCER \& REV. 3, 4 (1829).

185 American Law Periodicals, supra note 18, at 446.

${ }^{186}$ Swygert \& Bruce, supra note 18 at 753-54. See generally Note, Leading Articles in Law Periodicals, 22 AM. L. REV. 786, 786 (1888).

${ }^{187}$ American Law Periodicals, supra note 18, at 447. Mott referred to the American Jurist as "[p]erhaps the most important legal journal of 1825-1850 period. 1 MOTT, supra note 18 at 451 . In the second edition of his Course of Legal Study, David Hoffman advised his students to read the legal periodicals, especially the "admirable works" in the American Jurist. DAVID HofFMAn, A COURSE OF LEGAL STUDY 669 (2d. ed. 1836). On the first years of the journal and its coverage of codification, see [Grinnell] supra note 36 at 323-26. Willard Phillips, who "conducted [it] for some years" was also "a chief member of the group which conducted the North American Review." 1 MoTT, supra note 18 at 154.

${ }^{188}$ Story, Suffolk Address, supra note 3. A review of the first issue of the American Jurist in the North American Review focused on Story's speech. See [John Cochran Park], The American Jurist. No. I, 29 N. AM. REV. 418 
The Jurist published reviews of new reports throughout its run, beginning in 1829 with a review of the first volume of Richard Peters's U.S. Supreme Court decisions. The reviewer saw Peters as an improvement on Wheaton, while criticizing him for "heap[ing] into his abstracts incidental observations, reflections, and reasonings of the court ... serv[ing] to bewilder, rather than to assist the reader."189 An 1830 review of Peters's second volume presented examples of 'the absurd system on which the abstracts in this volume are prepared,"190 concluding that "there is scarcely a single abstract in the volume which states the points in the case definitely and tersely and which is not open to serious objections." ${ }^{191}$ Later that year, however, the Jurist praised the first volumes of Peters's Condensed Reports of Cases in the Supreme Court of the United States, not only for his plan to condense the reports of Dallas, Cranch, and Wheaton from 24 volumes to six, but for providing abstracts missing from cases reported by Dallas. ${ }^{192}$

The American Jurist's reviews of state court reports typically focused on the substance of the reported cases, but also emphasized the importance of good reporting. ${ }^{193}$ An early review of Thomas Day's Connecticut Reports pointed out that, in addition to opinions provided by the judges, the reporter's skill should be applied to writing a statement of the case, presenting the arguments of counsel, drafting a summary or abstract, and creating an index. ${ }^{194}$ The reviewer outlined the skills needed for each component, then applied them in detail to Day's work, ${ }^{195}$ suggesting the difficulties reporters faced in light of the growing numbers of reports. $\mathrm{He}$

(1829). Story had apparently declined an offer to publish the talk nearer the time of its delivery in 1921. See To the Public, supra note 86 at ii, n. *.

${ }^{189}$ Review of Richard Peters, U.S. Reports (1828), 1 AM. JURIST \& L. MAG. 177, 179 (1829).

${ }^{190}$ Review of Richard Peters, U.S. Reports (1829), 3 AM. JURIST \& L. MAG. 101, 104 (1830)

${ }^{191} I d$. at $108-09$.

${ }^{192}$ Review of Richard Peters, Condensed Reports of Cases in the Supreme Court of the United States (1830), 4 AM. JuRIST \& L. MAg. 417,418 (1830). See also Review of Richard Peters, Condensed Reports of Cases in the Supreme Court of the United States (1830), JURISPRUDENT, May 14, 1831, at 334.

The publication of Peters's Condensed Reports ultimately resulted in the Supreme Court's ruling in Wheaton v. Peters, 33 U.S. (8 Pet.) 591 (1834), which established that the reporters held no copyright in the Court's opinions. For background on the case and the decision, see Joyce, supra note 57 at 1364-86.

193 See, e.g., Review of Charles Penrose \& Frederick Watts, Pennsylvania Reports (1832); William Rawle, Pennsylvania Reports (1833), AM. JURIST \& L. MAG. 81, 109 (1833) (urging reporters to publish advance sheets or "numbers" in order to make the cases more quickly available); Review of Thomas Harris \& Richard W. Gill, Maryland Reports (1828; Thomas Day, Connecticut Reports (1830), AM. JURIST \& L. MAG. 314 (1830); Review of Simon Greenleaf, Maine Reports (1829), AM. JURIST \& L. MAG. 132 (1830); Review of Isaac Blackford, Indiana Reports (1830), 7 AM. JURIST \& L. MAG. 326 (1832); Review of H. Bailey, South Carolina Reports (1833); W.R. Hill, South Carolina Reports (1834), 12 AM. JuRIST \& L. MAG. 233 (1834); Review of Daniel Call, Virginia Reports (1833, 12 AM. JuRIST \& L. MAG. 239 (1834); Review of Charles Clarke, New York Chancery Cases (1841); Murray Hoffman, New York Chancery Cases (1841), 26 AM. JURIST \& L. MAG. 38 (1841).

In 1839, the American Jurist published an annotated list of American reports. See G.G. [George Gibbs], American Reports, supra note 8 at 108. See also the summary of English and American reports at 2 AM. L. MAG. 271 (1844).

The Albany Law Journal updated G.G.'s list in a series of short articles published in 1871-72. See American Reports and Reporters - No. 1, 3 ALB. L.J. 451 (1871); American Reports and Reporters - No. II, 3 Alb. L.J. 466 (1871); American Reports and Reporters - No. III, 3 Alb. L.J. 490 (1871); American Reports and Reporters - No. IV, 4 AlB. L.J. 5 (1871); American Reports and Reporters - No. V, 4 ALB. L.J. 24 (1871); American Reports and Reporters - No. VI, 4 AlB. L.J. 40 (1871); American Reports and Reporters - No. 7, 5 ALB. L.J. 359 (1872); American Reports and Reporters - No. 8, 5 ALB. L.J. 376 (1872); American Reports and Reporters - No. 9, 5 ALB. L.J. 389 (1872); American Reports and Reporters - No. X, 6 ALB. L.J. 4 (1872-1873).

${ }^{194}$ Review of Thomas Day, Connecticut Reports (1828), 2 AM. JURIST \& L. MAG. 232, 235 (1829).

195 Id. at $235-43$. 
emphasized the importance of abstracts to navigate "the tide of decisions and treatises pouring in upon the profession." "Some of the abstracts in John Wendell's Reports of New York cases were found "to be longer than necessary"; some "to be overcharged" for following the language of the judge too literally. ${ }^{197}$ The abstracts in an 1829 volume of New Hampshire Reports were praised as "remarkably well made," the reviewer finding that "only one of the abstracts struck us as defective, and of the defects of this we have some doubt."198 A 1932 review of Benjamin Rand's editions of Tyng's Massachusetts Reports commented in detail on the marginal notes and abstract. $^{199}$

The American Jurist reviewers struggled with how to treat arguments of counsel. Day was praised for giving "enough of the arguments to present distinctly the points in controversy" and avoiding "any attempt at preserving what might be considered the eloquence of the advocates."200 In 1832 the reviewer of Hammond's Ohio Reports found that the arguments were "often stated too minutely and in many instances occupy far too much space."201 The following year a review of Hammond's Ohio Condensed Reports emphasized the importance of including the arguments for opinions in which courts avoided counsel's arguments or stated them indistinctly to weaken their force. ${ }^{202}$ The review criticized a state law that would exclude arguments from the published reports. ${ }^{203}$

The Jurist seemed to worry less over the growing number of published cases than other commentators, despite having published the 1821 speech in which Joseph Story feared that future lawyers would "be overwhelmed with their number and variety." ${ }^{204}$ In its review of Day's Reports, the Jurist wondered whether the evil posed by "the multiplicity of law books" was not "exceedingly overrated."205 The expansion of American commerce and industry brought new forms of property and social relations, prompting new legislation as well as more litigation. Increasing numbers of law reports and other books were inevitable as the courts applied new rules to particular cases, and "the more minutely these doctrines or propositions are followed out into all their ramifications and consequences--the more intelligible will be the laws, provided these

${ }^{196}$ Id. at 237 (For this reviewer, the importance of the abstract "would justify an elaborate scientific treatise presenting a minute analysis of the different forms of abstracts, with instances and illustrations of defects and excellencies." Id. at 328).

197 Review of John L. Wendell, New York Reports (1829), 2 AM. JuRIST \& L. MAG. 290, 293 (1829).

${ }^{198}$ Review of New Hampshire Reports, (1829), 3 AM. JURIST \& L. MAG. 109, 109 (1830). The review closed by noting: "We presume these reports to be made by Chief Justice Richardson, and regret that they do not come out in his name, for the title is certainly a very long one to cite. ... But the volume will, by and by, no doubt assume the name of the reporter, and to save the trouble and confusion occasioned by a change, it would be more convenient to call it at once Richardson's Reports." Id. at 114

${ }^{199}$ L.S.C., Review of Benjamin Rand, Rand's Editions of Tyng's Massachusetts Reports (1837), 18 AM. JURIST \& L. MAG. 401 (1838).

${ }^{200}$ Review of Day's Connecticut Reports (1828), supra note 194 at 237.

${ }^{201}$ Review of Charles Hammond, Ohio Reports, 7 AM. JURIST \& L. MAG. 261, 273 (1832).

${ }^{202}$ Review of Charles Hammond, Ohio Condensed Reports, 10 AM. JURIST \& L. MAG. 468, 469 (1833). Id.

${ }^{203}$ Without their publication, "judges, by the inherent indolence of human nature, may be too strongly tempted to avail themselves, by throwing difficulties and objections into the shade instead of overcoming them, and slurring over arguments instead of answering them." Id. at 469-70

${ }^{204}$ Story, Suffolk Address, supra note 3 at 13.

${ }^{205}$ Review of Day's Reports (1828), supra note 194 at 232. 
decisions and deductions are consistent with each other." As a result the growing number of law books and published cases should be viewed "rather as an advantage than an inconvenience." 206

The review of Hammond's Ohio Reports suggested that the increase in reports had tended "to meliorate the law, by supplying its deficiencies, and limiting the discretion, as well as enlightening the understandings of those, whose duty it is to expound and administer it." 207 No one could argue against publication of the reports, other than those unwilling to study the law as a science. The growth in number of reports should not be seen as a problem:

No human mind can, probably, even now, read and comprehend all, or but a very small part of what has been written, upon many of the sciences. ... Yet in all the sciences except that of the law, we rarely hear any complaint of the multiplicity of books, or any wish expressed, that the publication of good works upon any of these sciences should be prohibited. $^{208}$

As a practical matter, a lawyer need not read even a small portion of the published cases because, "by the means of indexes, digests, and books of reference, all that is really valuable is rendered accessible, and may be readily found by every well instructed reader."209

\section{Reviews in Later Antebellum and Post-Civil War Journals}

When the American Jurist ceased publication in 1843, the Law Reporter of Boston lamented its closing as an event that "strikingly manifests how little devotion there is at the present day ... to legal science." 210 In his study of nineteenth century American legal culture, Robert Ferguson suggested that in the face of the growing amount of American law, lawyers of the late antebellum period could no longer be generalists, but needed to specialize and to master particular areas of practice: "Technical competence triumphed over general learning and philosophical discourse as case law accumulated." 211 In the 1840s lawyers "began to accept the overriding complexity of the law as an intellectual norm. ... It was enough to find the detail and application of the law without worrying about comprehensiveness and theoretical compatibilities."212 The need to shift from

\footnotetext{
${ }^{206} I d$. at 234. After noting that a book being published did not mean that every lawyer had to read it, the review pointed out that one of the Jurist's objectives was to give its readers information about as many new books as possible to "enable them to distinguish ... what publications will be most worthy of their assiduous attention and study in their particular course of practice." Id. at 233.

${ }^{207}$ Review of Hammond's Ohio Reports, supra note 201 at 262.

${ }^{208} I d$. at 263

${ }^{209}$ Id. Compare with [Porter], Review of Paine's U.S. Second Circuit Reports (1827), supra note 147 at $180-81$. The American Jurist reviewer also compared American reports favorably to contemporary English Reports, in part because "the decisions of our judges are reduced to writing usually by the judges themselves." Review of Hammond's Ohio Reports, supra note 201 at 266. In both countries, however, reporters "seem[ed] to make it a principle object to stuff into their books as much as they can induce the public to receive." Id. at 269.

${ }^{210}$ Metcalf's Reports, 7 LAW REP. 1, 3 (1844). In an earlier issue, the Law Reporter noted the appearance of the American Law Magazine (Philadelphia) which "appears to be on the general plan of the American Jurist." Notice, 6 LAW REP. 187,187 (1843). In reviewing the Law Magazine in June 1844, it quoted the publishers' announcement that it was "in continuation of the American Jurist." American Law Journals, supra note 18 at 74.

${ }^{211}$ FERGUSON, supra note 40 at 200

${ }^{212}$ Id. at 287
} 
understanding general principles to what Ferguson called "textbook law" changed how lawyers approached their practice:

The early lawyer searched for a declaration derived from common usage and consistent with nature. His successor, the reader of case reports, thought in terms of the specific commands that society had placed upon itself. Each had a particular approach to the printed page. The first looked for connections and resemblance; the second, for distinction and precision. Their respective needs made general literature useful to the former and increasingly irrelevant to the latter. ${ }^{213}$

In noting the end of the Jurist, the Law Reporter concluded that "[ $\mathrm{t}]$ he indifference with which the learned profession of the law has witnessed the departure of its organ, certainly does not evince a very deep interest in professional discussion and research, or a very ardent desire for the advancement of jurisprudence." 214

For the rest of the antebellum period, legal journals focused on publishing new cases, along with other short features. Six were initiated in the 1830s, mostly for short runs: the Carolina Law Journal (1830-1831); the Journal of Law (1830-1831); ${ }^{215}$ The Jurisprudent $(1831)^{216}$; the CityHall Reporter and New York General Law Magazine (1833). Those with greater staying power were the Law Reporter (later the Monthly Law Reporter) (1838-1866); and Hunt's Merchant's Magazine and Commercial Review (1839-1861), each of which published occasional short reviews of new volumes of reports.

Thirteen new legal periodicals published their first issues in the 1840s; another 16 before 1860 . Fourteen lasted five or more years; notable among them: the Pennsylvania Law Journal (later

${ }^{213} I d$. at 200. Perry Miller observed that by the mid-1830s, "The science [of law] has now become so complex, and contains so many subjects which have little connection with each other...that to hope to turn out universal scholars of the law is to condemn the students to years and years of 'laborious research'." MILLER, supra note 38 at 142 (paraphrasing Benjamin F. Butler's 1835 plan for a law school at NYU).

${ }^{214}$ Metcalf's Reports, supra note 210 at 4. The Law Reporter saw itself as "intended for the workingmen of the profession." Preface, 1 LAW REP. iii, iv (1839).

Ten years later, a reviewer in the Monthly Law Review noted: "So little interest is, ordinarily, felt in what is called the literature of the law, or the history of jurisprudence, that they generally find but few readers." Reports of Massachusetts, 11 MONTHLY L. REP. 481, 481 (1849).

Some pre-War reviewers continued to see humor in the reports: In 1848 a review in Hunt's Merchant's Magazine found a volume of New York equity cases to hold "not only decisions of importance to the legal profession, but cases of much interest, we may say, entertaining cases, for the general reader." Sandford's Chancery Cases, 18 HunT's MERCHANTS' MAG. 628, 628 (1848). In 1861, the American Law Register found that the reader of a new volume of Massachusetts Reports would find not only "cases of the gravest moment and most difficult solution," but "he who is curious in the phases of social life will receive his quota of fun." Review of Massachusetts Reports, 9 AM. L. REG. 575, 576 (1861). See also Cases under the New Constitution of New York, 20 HuNT'S MERCHANTS' MAG. 75, 75 (1849) (review of Oliver Barbour, New York) (“many cases ... are interesting, not only to the lawyer, but also to the general reader....").

215 See Joel Fishman, An Early Pennsylvania Legal Periodical Journal of Law, 1830-31, 1 UnBOUND 33 (2008) (discussing the Journal's publication history and content).

216 On the Carolina Law Journal, The Jurisprudent, and the Journal of Law, see American Law Periodicals, supra note 18 at 447 . 
American Law Journal) (1842-1852); the Western Law Journal (1843-1853) ${ }^{217}$; the United States Monthly Law Magazine (later Livingston's Monthly Law Magazine) (1850-1856) ${ }^{218}$; and the American Law Register (later the University of Pennsylvania Law Review) (1852-present). ${ }^{219}$ Sixteen journals started publication in the 1860s; twelve of which lasted five or more years, most notably the American Law Review (later United States Law Review and New York Law Review) $(1866-1940){ }^{220}$ and the Western Jurist, (1867-1883). ${ }^{221}$ Hicks lists eight of the journals initiated between 1840 and 1869 both as periodicals and as Pennsylvania Miscellaneous Reports. ${ }^{222}$

\section{Reviews of State Court Reports}

After 1840, the Pennsylvania Law Journal/American Law Journal; the Western Law Journal, the Law Reporter/Monthly Law Reporter, the United States Monthly Law Magazine/Livingston's Monthly Law Magazine; and the American Law Register (from its first issue in 1852 until 1864) frequently reviewed volumes of reports. But the reviews were shorter than those written earlier, and focused more on technical and professional issues raised by the reports, than on broader societal and political concerns. ${ }^{223}$

Reviewers continued to debate how extensively to present arguments of counsel. The U.S. Monthly saw a "creeping tendency to interpolate the arguments of counsel" into the reports, ${ }^{224}$ and pointed out the need for selective reporting: "The rule is, and we would remind Reporters that it is a rule: that every case reported should be either remarkable as an example and luminous statement

${ }^{217}$ In 1870, the Albany Law Journal suggested that the Western Law Journal "maintained at the west that standard of excellence that the American Jurist had reared at the east." Id.

218 Michael Hoeflich calls Livingston's United States Monthly Law Magazine the first legal periodical aimed at "the national market." M. H. HoEFLICH, LeGAl PUBLiSHING IN ANTEBELlUM AMERICA 147 (2010) at 147. See also id. at 153-57; American Law Periodicals, supra note 18 at 448. In an 1844 review of contemporary law magazines, the Law Reporter took pains to note that despite its own Boston origins, over two-thirds of its readers resided outside New England. American Law Journals, 7 Law Rep. 65, 76 (1844).

219 See Appendix for a full list.

${ }^{220}$ Surrency called the American Law Review "[t]he most successful magazine of the post-Civil War period."). SURRENCY, supra note 18 at 191.The Albany Law Journal found its book reviews to be "fearless and impartial." American Law Periodicals, supra note 18 at 449.

${ }^{221}$ On the Western Jurist, see id.

${ }^{222}$ See Grace W. Bacon, List of American Law Reports in FREDERICK C. HiCKS, MATERIALS AND METHODS OF LEGAL RESEARCH 484, 505-07 (3d ed. 1942).

${ }^{223}$ Two 1851 reviews in the United States Monthly Law Magazine bemoaned the difficulties involved in obtaining satisfactory information about earlier American reports. A review of Alabama Reports provided references to the available sources. Review of N. W. Cocke, Alabama Reports (1850), 3 U.S. MonTHLY L. MAG. 355, 355-357 (1851). Another chided the reporter for a new series of New Jersey Reports for not explaining recent changes in state laws regarding reporting, stressing "the importance of having ready and reliable data by which to make up the history of American Reports - to determine their historical order and value, and to settle the history of the law." Review of A.O. Zabriskie, New Jersey Reports (1850), 3 U.S. MonTHLY L. MAG. 360, 360 (1851).

${ }^{224}$ Review of Iowa Reports (1849), 3 U.S. MONTHLY L. MAG. 115, 115 (1851). ("The arguments of counsel are from the wrong point of view for all the efficient purposes of reporting." Id.). The reviewer of Cocke's Alabama Reports found that the reports generally were "of late very crowded and bulky," mostly because "after a statement of the case, by no means remarkable for conciseness, we are treated to a barbecue [sic] of argument which as often consists of what we are to suppose counsel said on the hearing as it does of the points which they made." The reviewer did not know whether a statute required publication of the arguments, but "if not, in the name of the profession and propriety we wish to take out a writ of prohibition." Review of Cocke's Alabama Reports (1850), supra note 223 at 357. 
of conceded law, or ... that the new case really does disapprove, explain, or distinguish other cases going before it." 225 Concerned about the growing number of reports and other books lawyers needed to purchase, they noted the impacts of requirements that judges file written opinions and reporters publish all opinions. ${ }^{226}$ Looking back, Carl Swisher found "widespread disagreement...as to the subject matter to be included in the reports. The question was much discussed in law and other learned journals. ${ }^{227}$

\section{The Law Reporter / Monthly Law Reporter}

The Boston-based Law Reporter (which became the Monthly Law Reporter in 1848) reviewed state reports from New England, New York and Pennsylvania, and occasionally from other states. The Law Reporter frequently offered high praise for Massachusetts reporter Theron Metcalf, ${ }^{228}$ characterizing him as "one of the soundest, most accurate and learned lawyers of our country."229 Yet, the journal could fault even Metcalf for not giving enough of the arguments of counsel:

No better mode has yet been discovered to establish judicially either fact or law, than by the agency and discussion of opposing counsel ... we wish always to see what points were distinctly presented for decision, and what views were taken by the respective counsel; without these it is impracticable to determine whether or not the opinion of the court covers the whole case, as prepared and presented for adjudication by the counsel, who had it in charge. ${ }^{230}$

${ }^{225}$ Review of James Iredell, North Carolina Reports (1850), 3 U.S. MonTHLY L. MAG. 117, 117 (1851).

${ }^{226}$ For descriptions of requirements for written opinions in 15 states from 1789-1860 see Popkin, supra note 13 at 183. According to Hicks, the number of volumes of published reports grew from 5 in 1801, to 180 in 1819, to 452 in 1836, to 800 in 1848, and to 2,000 in 1871. HICKS, supra note 13 at 111.

${ }^{227}$ CARL B. SwISHER, THE TANEY PERIOD, 1836-64, at 296 (2009) (Vol. 5. History of the Supreme Court of the United States). Many reviewers also commented about the physical quality and appearance of new volumes of reports. See Review of Thomas Day, Connecticut Reports (1853), 5 AM. L. REG. 191, 192 (1857) (condemning a New Jersey law that entrusted printing of the reports to newspaper printers).

${ }^{228}$ See Review of Theron Metcalf, Massachusetts Reports (1842), 5 LAW REP. 523, 523 (1843) ("the volumes of Mr. Metcalf are, on the whole, the best of the American Reports...they may well serve as models for reporters on both sides of the Atlantic."); Review of Theron Metcalf, Massachusetts Reports (1851), 14 MONTHLY L. REP. 100, 100 (1851) ("Metcalf's Reports are excelled by none, either in this country or in England."). The Law Reporter also regularly praised the work of Thomas Day, who served as Supreme Court reporter in Connecticut for nearly fifty years. See e.g., Day's Connecticut Reports, 9 LAW REP. 433 (1847) ("Mr. Day is unquestionably the oldest living reporter." Id. at 433.). See also Review of Thomas Day, Connecticut Reports (1853), 1 AM. L. REG. 574, 574 (1853) ("No State Reports have been more deservedly esteemed than Day's....").

${ }^{229}$ Metcalf's Reports, supra note 210 at 1.

${ }^{230} I d$. at 9. Reviewing a later volume, the Law Reporter noted that Metcalf had adopted some of its suggestions regarding arguments of counsel and "now observes the just medium." Review of Theron Metcalf, Massachusetts Reports (1846), 9 LAW REP. 329, 330 (1846).

In 1857, a reviewer praised Metcalf's successor for his handling of "the delicate and difficult" question of arguments of counsel, and applying "a general rule to supply whatever of the points and authorities relied on may be necessary to give a complete view of the case on both sides, and especially to show the positions taken by the losing side. We do not think that any better principle can be laid down...." Review of Horace Gray, Massachusetts Reports (1857), 19 MONTHLY L. REP. 656, 657 (1857). Later that year, the New Hampshire reporter was criticized for "suffer[ing] the counsel to usurp much space that might have been profitably devoted to the insertion of additional cases." Review of George C. Fogg, New Hampshire Cases (1857), 20 MONTHLY L. REP. 478, 479 (1857). In 1863 the Reporter criticized a volume of Massachusetts Reports for not presenting enough of the arguments of counsel: "An argument is often quite as instructive as the opinion of the court. In cases of novel impression the arguments on 
Echoing James Kent's 1826 comments on the value of the reports, the reviewer went on also to note that the arguments furnished " $[\mathrm{t}]$ he only memorial, in any permanent form, which in general is preserved, of even the most eminent lawyers.... The reporter is the lawyer's poet; he alone records his deeds and perpetuates his fame. It is matter of regret that so little is generally preserved of the most distinguished lawyers." 231

Metcalf's reviewer was less favorably inclined toward judge-written opinions than oral arguments, crediting the length of the opinions in his reports to "[t]he fact, that the opinions are drawn up fully by the judges themselves at their convenience." 232 This led to longer opinions, often for cases that called only for "an application of settled principles"233 An 1855 review of the first volume reported by Metcalf's successor, Horace Gray, regretted "that the reporter is not at liberty to omit cases of no value," but was required by statute "to publish reports of the decisions on all legal questions argued by counsel, although of no earthly importance to any one [sic] but the parties." 234

The Law Reporter was also less generous to Maine reporter John Shepley than to Metcalf and Gray, in March 1844 publishing a review of volume 21 of the Maine Reports, written by someone described as "a gentleman fully competent to express an opinion on the subject, who never lived in Maine, and has no personal knowledge of the court there." 235 The review criticized the quality of Maine lawyers, the Maine Supreme Court, Shepley the reporter, and the impacts of partisan politics on the Maine judiciary. ${ }^{236}$ In May the New York Legal Observer reprinted part of the review under the title: "Massachusetts v. Maine," characterizing it as "a sort of punitory homily upon the jurisprudence of Maine." 237 Later that year, the Law Reporter published a second review of volume 21 on the request of another "gentleman who, in a successful practice of more than twenty years, has earned a right to be heard upon any occasion and at any tribunal where the law is discussed." 238 The new reviewer was more favorable to the quality of the volume at issue, but began his review by striking out at the burgeoning number of law books:

[E]very new law book is, to the extent of its price, a direct tax, a sort of black mail, exacted,nolens volens, from a profession, low in number, and whose labor is more scantily remunerated than that of any other class in the community ... the illimitable spawning of law books, which has increased with locomotive velocity within the last thirty years, is becoming, if it has not already become, an intolerable burden. ${ }^{239}$

both sides should be presented. And in the majority of cases the argument and points of the losing party should be reported." Review of Charles Allen, Massachusetts Reports (1863), 25 MONTHLY L. REP. 686 (1863).

${ }^{231}$ Metcalf's Reports, supra note 210 at 11.

${ }^{232} \mathrm{Id}$. at 12.

${ }^{233} \mathrm{Id}$. at 13. Two years later, the Law Reporter blamed delays in publishing the reports to "the American system of the judges writing out their opinions." Review of Metcalf's Reports (1846), supra note 210 at 329.

${ }^{234}$ Review of Horace Gray, Massachusetts Reports (1854), 17 MONTHLY L. REP. 535, 435 (1855). See also Review of Foster's New Hampshire Reports (1855),18 MONTHLY L. REP. 179, 179 (1855) ("It is, perhaps to be regretted, that the judges and the reporter are not at liberty to exercise a judicial discretion in the selection of cases.").

${ }^{235}$ Review of John Shepley, Maine Reports (1843), 6 LAW REP. 519, 527 (1844).

${ }^{236} \mathrm{Id}$. at 520 .

${ }^{237} 5$ N.Y. LEGAL OBSERVER 81, 81 (1844).

${ }^{238}$ Review of John Shepley, Maine Reports (1843), 7 LAW REP. 44, 44 n. 1 (1844).

${ }^{239} \mathrm{Id}$. at 44. The same year, the editor of the Western Law Journal pointed out the impacts on a lawyer's salary of purchasing even half of the number of American and English Reports published annually, suggesting that reporters 
In the same issue the "fully competent" gentleman who had spawned the controversy offered a review of New Hampshire Reports, in which he noted that his criticisms of the Maine Reports "were intended to apply to the character of the supreme court of Maine," apparently not to others such as Reporter Shepley. ${ }^{240}$ In March 1845, "a highly respectable practitioner in Maine" reviewed a later volume of Maine Reports, which praised the opinions of the Maine court and the work of the reporter, but criticized Theron Metcalf's latest volume of Massachusetts Reports for including fewer cases than Shepley (at a greater price) and taking up "more space with arguments of counsel than many would deem necessary or important." ${ }^{241}$ In a note, the Law Reporter pointed out that "we dissent widely from some of the writer's opinions in the present notice, especially where he says that Mr. Metcalf's reports of the arguments of counsel are too long." 242

\section{Pennsylvania Law Journal / American Law Journal}

In its early volumes, the Pennsylvania Law Journal (which became the American Law Journal in 1848) ${ }^{243}$ subjected Pennsylvania Reports to close examination and criticism. In 1842, the Journal reprinted a highly critical review from "one of our city papers" of the first reports prepared by Frederick Watts and Henry Sergeant. ${ }^{244}$ The reviewer blamed the poor quality of these and earlier reports for the lack of national respect for Pennsylvania precedents, then said of the most recent volumes that "worse prepared, more slovenly, more defective in every quality of good reporting, or, in short, more utterly unreadable, we have never had the task of studying," even when compared to "the reports of the far western states." 245

Watts and Sergeant's third volume provided only "imperfect relief." Too many cases dealt with "no principle whatsoever [and] interest nobody beyond the parties to the suit." 246 The reviewer concluded: "We have too much respect for [Watts and Sergeant] to iterate the charge, elsewhere made against them, that being paid a precise sum for every volume that they can make, they have forgotten their sense of reputation and their sense of duty." 247 Still the reports were worse than those published in "Mormon Illinois," "savage Arkansas," or "shameless Mississippi." "248 In 1846 the Journal used a review of Watts and Sergeant's eighth (and final) volume to praise a new Pennsylvania law establishing an office of state reporter. ${ }^{249}$

When the official Pennsylvania reporter issued his first volume, the Law Reporter used the occasion to criticize judge-written opinions as likely to feature "tedious length, the endless

be required to condense each case, and that the books be printed by a public printer at prices fixed by law to cover publishing costs and the reporter's salary. By the Editor, Blackford's Reports, 1 W. L.J. 476, $477-78$ (1844).

${ }^{240}$ Review of New Hampshire Reports (1843), 7 LAW REP. 48, 49 (1844).

${ }^{241}$ Review of John Shepley, Maine Reports (1845), 7 LAW REP. 540, 540 (1845).

${ }^{242} I d$. at 540 n.1

${ }^{243}$ See Joel Fishman, An Early Pennsylvania Legal Periodical: The Pennsylvania Law Journal, 1842-1848, 45 AM. J. LEGAL HIST. 22 (2001) (discussing the Journal's publication history and content).

${ }^{244}$ Review of Frederick Watts and Henry J. Sergeant, Pennsylvania Reports (1842), 1 PENN. L.J. 22, 23 (1842).

${ }^{245} I d$. at 24.

${ }^{246}$ Review of Frederick Watts and Henry J. Sergeant, Pennsylvania Reports (1843), 2 PENN. L.J. 129, 131-32

(1843).

${ }^{247} I d$. at 135

${ }^{248} I d$. at 136.

${ }^{249}$ Review of Frederick Watts and Henry J. Sergeant, Pennsylvania Reports (1846), 5 PENN. L.J. 144, 144 (1846).

The review criticized a provision excluding publication of dissenting opinions. 
discussions of collateral points, and [an] essay-like character," and to include too much dicta. ${ }^{250}$ In 1848 the American Law Journal sounded a similar note, criticizing a New Jersey written opinions requirement because "judges have seldom time or disposition to prepare a concise and yet complete statement of the case ... and the reporter has little opportunity, and generally less inclination" to do so. ${ }^{251}$

\section{American Law Register}

The American Law Register, which continues today as the University of Pennsylvania Law Review, published short reviews of reports from its first issue in 1852 until 1864, regularly registering concern about requirements that all cases be published. ${ }^{252}$ In 1854 a volume of New York Surrogate's cases was praised because it did not include cases "the points of which have not been seriously disputed for generations." 253

In 1862 reviewer I.F.R. praised the quality of a new volume of New Jersey Reports, but commented that "the largest number of cases which find their way into the reports in this country are too insignificant... to command that serious examination or consideration ... requisite to give the decision the character of authoritative precedent." ${ }^{254}$ A review of a new volume of Illinois Reports characterized a requirement that all cases be published as a "disease ... seriously fatal to all advancement in juridical knowledge or in rational reform." 255 The next volume of Illinois Reports was praised for the brevity of the opinions, a necessity given the number of opinions now required to be published. ${ }^{256}$ An 1863 review of Allen's Massachusetts Reports pointed out that statutes requiring all decisions to be published effectively gave them all equal importance. ${ }^{257}$ In 1864, a volume of Kerr's Indiana Reports was found to be "crowded with an infinite number of useless cases, and by consequence the important cases are far too briefly discussed, and the arguments of counsel almost entirely excluded." 258

${ }^{250}$ Review of Robert M. Barr, Pennsylvania Reports (1846), 9 LAW REP. 138 (1846)

${ }^{251}$ Review of Robert D. Spencer, New Jersey Reports (1847), 8 Am. L.J. 273, 274 (1848).

252 The Register's reviewers (typically identified by initials) often compared new volumes of reports to those already issued. See, e.g., Review of Samuel Ames, Rhode Island Reports (1859), 7 AM. L. REG. 256, 256 (1859) (deeming Ames's volume to be "decidedly one of the very best volumes of law reports we have had occasion to look into in a long time"); Review of George F. Moore and Richard S. Walker, Texas Reports (1860), 8 AM. L. REG. 763,764 (1860) (finding reporting of Texas cases to be "fully equal to that of any state in the union"); I.F.R., Review of Horace Gray, Massachusetts Reports (1864), 12 AM. L. REG. 382, 382 (1864) (finding the final volumes of Gray's Reports "indispensable to complete the series"); I.F.R., Review of Michael Kerr, Indiana Reports (1864), 12 AM. L. REG.702, 703 (1864) (deeming the volume to be "of more than ordinary value").

${ }^{253}$ Review of Alexander Bradford, New York County Surrogate Court Cases (1854), 2 AM. L. REG. 384,384 (1854).

${ }^{254}$ I.F.R., Review of Andrew Dutcher, New Jersey Reports (1861), 10 AM. L. REG. 189, 189 (1862).

${ }^{255}$ I.F.R., Review of E. Peck, Illinois Reports (1862) [v. 25], 10 AM. L. REG. 319, 319-20 (1862).

256 I.F.R., Review of E. Peck, Illinois Reports (1862) [v. 26], 10 AM. L. REG. 701, 701 (1862).

${ }^{257}$ I.F.R., Review of Charles Allen, Review of Massachusetts Reports (1861, 1862), 11 AM. L. REG.191,192 (1863).

${ }^{258}$ I.F.R., Review of Michael C. Kerr, Indiana Reports (1863), 12 AM. L. REG. 190, 191 (1864). For similar comments, see I.F.R., Review of Thomas F. Withrow, Iowa Reports (1864), 12 AM. L. REG. 639, 640 (1864) (“The majority of the cases involve no new principle, or any application of old ones. But this is true of all our reports."). Similar thoughts were expressed in other journals. See, e.g., C.A.C., Review of Truman A. Post, Missouri Reports (1874), 2 CENT. L.J. 320, 320 (1875) (publishing all decisions "contributes largely to make the reports of our state....among the poorest now offered to the public and the profession."); Review of Norman L. Freeman, Illinois Reports (1876), 3 CENT. L.J. 713, 713 (1876) (requirement contributes to the immense number of cases heard by the Supreme Court, "without any regard as to their value to the profession."). 
Like other journals, the Law Register criticized judge-written opinions. In 1862 T.W.D. wrote that "most of the time spent by judges in composing extended and elaborate opinions would often be far more profitably employed in making a condensed statement of the reasons for the judgment, and in skilfully distinguishing the case from prior decisions." ${ }^{259}$ Reviewing Grant's Pennsylvania Reports, an unofficial series of Pennsylvania Supreme Court cases, J.T.M. wrote that because they "are compelled by law to write their opinions in every case...the judges have marked a very large majority of the cases decided by them to be reported." 260

\section{Reviews of U.S. Supreme Court Reports}

Harshly criticism of U.S. Supreme Court reporters was common before and after the Civil War, particularly for Benjamin C. Howard, who succeeded Richard Peters in 1843 and continued through 1860. The Law Reporter found that Howard's first volume "entirely disappointed" its expectations that he would improve on Peters ${ }^{261}$ : he reported few cases, the cases were of little interest, and the volume was seen as padded with materials such as Howard's business card that added little to its value. ${ }^{262}$

In 1844 the American Law Magazine reviewed Howard's initial volumes, suggesting that although the first was perhaps not a fair test of his abilities, including the business card had been "undignified and unprofessional." 263 The second volume had "decidedly improved," but was deficient in reporting arguments of counsel. ${ }^{264}$ The Pennsylvania Law Journal agreed that Howard's second volume was an improvement, noting that "[ $\mathrm{t}]$ he censure which was so well bestowed upon the previous volume by the "Law Reporter" has had a salutary effect."265 In 1846, the Law Reporter noted that Howard's statements of cases and arguments could have been better condensed, "as is done by the most approved reporters." 266 An 1851 Western Law Journal review compared Howard's ninth volume unfavorably to the latest of Smith's Indiana Reports, noting that Howard's were "stuffed with exhibits and pleadings in hac verba, as if it were not the duty of a reporter to strip the case of all matter, foreign to the immediate point decided."267

\footnotetext{
259 T.W.D., Review of Oliver Barbour, New York Reports (1862), 10 AM. L. REG. 255, 255-56 (1862).

260 J.T.M., Review of Benjamin Grant, Pennsylvania Reports (1864), 12 AM. L. REG. 511, 512 (1864). Those not included in the official reports were published by Grant and considered to be of equal authority with those published officially.

${ }^{261}$ Review of Benjamin C. Howard, U.S. Reports (1843), 6 LAW REP. 284, 284 (1843).

${ }^{262} I d$. at 284-85. Howard's first volume was issued against a competing volume for the same term issued by his predecessor Richard Peters. The Western Law Journal offered a short note on Peters's unofficial compilation which concluded that "This unofficial volume is not only an improvement over its predecessors, but is much superior to its official rival.” Miscellaneous, 1 W.L.J. 83, 84 (1843). See also SwISHER, supra note 227 at 305-06.

${ }^{263}$ Review of Benjamin C. Howard, U.S. Reports (1843, 1844), 4 AM. L. MAG. 226, 227 (1844).

${ }^{264} \mathrm{Id}$. The review also discussed Peters's elaborate approach to writing syllabi, and wondered whether Howard was being ironic in creating a complicated Peters-like syllabus in one case. Id. at 228-29.

${ }^{265}$ Review of Benjamin C. Howard, U.S. Reports (1844), 3 PENN. L.J. 476, 476 (1844).

${ }^{266}$ See Review of Benjamin C. Howard, U.S. Reports (1846), 9 LAW REP. 229, 229 (1846)(citing an 1830 note from Justice Marshall authorizing Richard Peters to condense the reports in order to avoid printing two volumes per term. 28 U.S. (3 Peters) v-vi (1830)).

${ }^{267}$ Reviews of Benjamin C. Howard, U.S. Reports (1851), Thomas L. Smith, Indiana Reports (1850),8 WESTERN L.J. 296, 296-7 (1851)
} 
In 1855 the Monthly Law Reporter detailed its objections to Howard's reporting style, calling his reports "deficient,--perhaps it is justifiable to say, scandalously deficient." 268 The duty of a reporter was not to pad the volumes, but "to give the decision of the court (now always written by the judges themselves), and so much of a statement of necessary facts as the opinion does not disclose." In leading cases, "it is well...to give the points and authorities of counsel on the losing side, and, in some cases, on both sides. Then he is expected to put the substance of the matter actually decided in marginal notes."269 Howard's notes were poorly done as were the indexes to his volumes:

In the multiplicity of reports at the present time, lawyers must rely a good deal upon digests, and it is known that digests are made up very much from the indexes of the reports. Whenever, therefore, we see a poor index to a volume of reports, we feel that the source of knowledge is corrupted at the head. The indexes to Howard's Reports are poor, perhaps as poor as those of Peters, which have generally been considered the standard of incorrectness. ${ }^{270}$

The following year, however, the Monthly Law Reporter found that Howard had improved, having abandoned the idea of including "a confused mass of papers and documents, of but little service to the reader," and generally reporting cases briefly with accurate notes. ${ }^{271}$ In 1857 , however, after noting how hard it was to find a very bad law book to review, the American Law Register decided it had found one in Howard's nineteenth volume. Noting that "A bad reporter always earns our unmixed reprobation," the reviewer ranked Howard "among the public enemies," finding that " $[t]$ he first of these volumes were wretched; complaints and remonstrances were made, and the last of these volumes are still wretched."272 Particularly poor were the treatments of the arguments of eminent counsel such as Webster, Clay, and Binney, which Howard "so botched and mangled and belittled that not even the torso of the colossus remains." 273 The reviewer suggested that Howard find a competent deputy to prepare the reports issued under his name. ${ }^{274}$

In 1856, sitting Supreme Court Justice Benjamin R. Curtis completed a compilation of Supreme Court opinions from 1790-1854 (including those in Howard's first 17 volumes). The Monthly Law Reporter praised Curtis for condensing the earlier volumes, noting that some reporters "had allowed their records to be overlaid with irrelevant material of various kinds, so that the true points of a case were often effectually hidden." ${ }^{275}$ Yet, the review also questioned Curtis's elimination of some information, "especially the arguments of the losing side, and of such arguments as were in times past not seldom addressed to that court. ... Brevity, the soul of wit, is sometimes the parent of obscurity." 276

${ }^{268}$ Review of Benjamin C. Howard, U.S. Reports (1855), 18 MONTHLY L. REP. 296, 296 (1855).

${ }^{269} I d$.

${ }^{270} I d$. at 297. The review closed by noting "the great length at which the arguments of counsel are given." Id. at 298.

${ }^{271}$ Review of Benjamin C. Howard, U.S. Reports (1856), 19 MONTHLY L. REP. 473, 473 (1856).

${ }^{272}$ Review of Benjamin C. Howard, U.S. Reports (1856), 5 AM. L. REG. 755, 757-8 (1857).

${ }^{273} \mathrm{Id}$. at 758 (1857)

${ }^{274} I d$. at 759 (1857)

${ }^{275}$ Review of Benjamin R. Curtis, Reports of Decisions of the Supreme Court of the United States (1855-1856),19 MONTHLY L. REP. 112, 113 (1856)

${ }^{276}$ Id. In an 1857 review of Curtis's own decisions in the $1^{\text {st }}$ Circuit, the Monthly Law Reporter noted that "Judge Curtis never gives the arguments, or even the points or authorities of counsel. We think it is well in leading cases, to 
In a longer review published in 1863, the Monthly Law Reporter again criticized Curtis's decision to eliminate arguments of counsel in his condensed reports, noting that

[A]n argument is often quite as instructive, to say the least, as the opinion of the court; many of the cases contained in this series were of novel impression. In such cases we are decidedly of the opinion that the arguments on both sides should be presented. And we are also of opinion that in many cases the argument of the losing party should be reported. 277

In 1861, Howard was succeeded as reporter by Jeremiah S. Black. In its review of Black's first volume, the American Law Register greeted his appointment as one of those rare occasions on which the merit of the postulant has surpassed the measure of the office." 278 Referring to Howard's tenure, the review noted found that "it would be both ungracious and unnecessary now to speak."279 Black resigned in 1864 after publishing two volumes. John W. Wallace succeeded Black, serving until 1874.

Wallace would be the last reporter of U.S. Supreme Court Reports whose name was acknowledged on the spine of the volumes he reported. ${ }^{280}$ In 1865 the Monthly Law Reporter praised his first volume, finding it to be "at once accurate and scholarly," and noted that he claimed to follow the principles of good reporting set forth by Story in his letter to Peters. ${ }^{281}$ The review quibbled only with his placement of facts and complained that the Court was issuing too many dissenting opinions. ${ }^{282}$ In 1867, however, the American Law Review offered a highly critical review of Wallace's first three volumes. ${ }^{283}$ Noting that the seriousness and importance of the issues faced by the Court after the Civil War demanded "the highest qualities of a reporter," 284 the review detailed his shortcomings: "we cannot fail to observe how very much we have of the reporter, and

give, at the discretion of the reporter, the points and authorities at least of the losing side." Review of Benjamin R. Curtis, U.S. First Circuit Reports (1857), 19 MONTHLY L. REP. 658, 658 (1857).

${ }^{277}$ Review of Benjamin R. Curtis, Reports of Decisions of the Supreme Court of the United States (1855-1856), 25 Monthly L. Rep. 689, 693 (1863). This point was followed by a full quotation of Story's 1836 letter to Peters regarding the duties of a reporter, which the review said accorded with its own views. See Letter from Joseph Story to Richard Peters, May 7, 1836, in 2 STORY, LIFE AND LETTERS, supra note 103 at 231-232.

${ }^{278}$ H.W. Review of Jeremiah S. Black, U.S. Reports (1862), 10 AM. L. REG. 702, 702 (1862). A brief note in the Monthly Law Reporter found that the arguments of counsel might have been further abridged. See Review of Jeremiah S. Black, U.S. Reports (1862), 25 MONTHLY L. REP. 126, 126 (1862).

${ }^{279}$ H.W., Review of Black's U.S. Reports, supra note 278 at 703.

${ }^{280}$ Starting with volume 91 for the 1875 term, the bindings of new volumes bear only the volume number and the year of the term included.

${ }^{281}$ F.F.H., Review of John William Wallace, U.S. Reports (1864), 27 MONTHLY L. REP. 1, 2 (1865). Wallace's 1849 volume of reports from the Third Circuit had been praised in the American Law Journal. See Review of John William Wallace, U.S. Third Circuit Reports (1849), 9 AM. L.J. 431 (1849).

${ }^{282}$ F.F.H., Review of Wallace's U.S. Reports (1864), supra note 281 at 5-6.

283 Wallace's Reports, 1 AM. L. REV. 229 (1867).

${ }^{284}$ Id. at 230:

The task of a reporter, however difficult its performance, is perfectly well understood by the bar. His headnotes should be absolutely brief, clear, and correct. He should state such facts only as raise the law of the case. The argument of the losing side should be reported so far only as will suffice to show the ground upon which the case was put; and it is never amiss to print the names of the cases cited by both parties. And, in every part of his work, the reporter should never forget that brevity, terseness, and the most careful choice of words, are his highest duties. 
how little of the court." In one case, "we have eleven pages of statement of the case, and six only of the opinion of the case" ${ }^{285}$; in many others he "seems to have copied the briefs verbatim." 286 His headnotes were constructed "in a loose and heedless way." The review went on:

Concerning this method of reporting, we have a perfectly distinct opinion which we do not hesitate to express. It is disrespectful to the high tribunal whose decisions Mr. Wallace reports. It is a fraud upon the profession who buy these costly volumes, and have a right to demand that they should not pay for rhetoric which would be dear at any price. It is a discredit to the American bar, whose learning and culture Mr. Wallace misrepresents in the eyes of all who consult his reports. And it is an exhibition of impertinence, triviality, and incompetency unique in the records of our jurisprudence. ${ }^{287}$

In conclusion the review characterized Wallace as "an incompetent public official [who] should cease to be reporter." 288

\section{Conclusion: West's Reporters and the Journals}

Forty-two new law journals began in the 1870s: seventeen lasted five years or more. ${ }^{289}$ Most notable among them were the Albany Law Journal (1870-1909); the Southern Law Review Old Series/New Series (1872-1882); the American Law Record (1872-1887); the Weekly Jurist/Monthly Western Jurist/Monthly Jurist (1874-1881); the Central Law Journal (1874-1927); and the Virginia Law Journal (1877-1893). ${ }^{290}$ Anticipating greater stability in the publication of legal journals, in 1872 the two year old Albany Law Journal noted that "law was the last of the great professions to accept journalism as a means of advancement and power," but optimistically declared that legal journalism was now:

an almost indispensable auxiliary to the profession by the early publication of legal news, of important decisions from all parts of the world, of abstracts and digests of opinions of judges in the courts of last resort far and near, and of well-written, able and elaborate articles on new or doubtful legal subjects. Law journals are also the means of the dissemination of the views of distinguished men upon topics of vital interest to the profession, not only in its internal and legal relations, but in its external and social and political relations. ${ }^{291}$ 
By 1875 , however, the Journal was much less enthusiastic, remarking that of the dozen or so current legal journals "a good part ... contain very little, if any reading matter beyond reports of cases. ${ }^{292}$

After the Civil War, legal periodicals published few reviews of reports. The Western Jurist published substantial reviews of the Iowa Reports and the Sandwich Island Reports in its first two volumes in 1867 and $1868,{ }^{293}$ then several short reviews in 1880. The Central Law Journal published short reviews from its first volume in 1874 through 1885. Other journals published occasional reviews. ${ }^{294}$

By the 1870s, American lawyers were less concerned with the literary merits of published reports and the hallmarks of good reporting than with the increasingly burdensome number of cases being reported and delays in their official publication. ${ }^{295}$ Most would have agreed with a comment in a Western Jurist review regarding the impacts of law reporting on the costs of law books:

The subject of law reporting is beginning to be of paramount importance to the legal profession; reports have multiplied and are multiplying so fast, and prices range so high, that practitioners will have to depend upon public libraries at much inconvenience, or content themselves with a single series of reports of one State, with the U. S. Digest and a limited number of text books. To possess a full library now of American law books, is to possess what has cost a fortune. ${ }^{296}$

Despite complaints about the continuing growth in the amount of published law, the Albany Law Journal defended publication of all cases. Despite the costs, the more cases reported, "the more likely are we to find the opinions and judgments of wise and experienced judges upon cases similar to those we may have in hand. And we all of us know how valuable is even one good

${ }^{292}$ Current Topics, supra note 158 at 1 . Of course that had been the case throughout the century.

${ }^{293}$ See H., The Iowa Reports, 1 W. JURIST 216 (1867); E.W., The Sandwich Islands' Reports, 2 W. JURIST 138 (1868).

294 The Virginia Law Register published two reviews of Virginia Reports late in the century. See James C. Lamb, Review of Martin P. Burks, Virginia Reports (1896), 2 VA. L. REGISTER 233 (1896); W.M.L., Review of Martin P. Burks, Virginia Reports (1896), 2 VA. L. REGISTER 708 (1897).

${ }^{295}$ In 1878, reviewer E.S. Hammond wrote that "The general public is not alive to the importance of having the adjudications of the Court of last resort speedily published; and there is a notion that nobody is interested in the books of reports but the lawyers." E.S. Hammond, Baxter's Reports, 1 MEM. L.J. 101, 104 (1878).

${ }^{296}$ H., The Iowa Reports, supra note 293 at 216 (1867). At the second meeting of the American Bar Association in 1879, the Committee on Jurisprudence and Law Reform found that:

Well endowed [sic] public libraries alone can afford the funds or the shelf room they require. The Federal reports, limited to the Supreme Court of the United States, and the Circuits and Districts which until lately have afforded scanty materials for the reporter, now number over 200 volumes. The reports of the State courts of New England and New York alone have reached nearly 750 volumes, while the remaining thirty-two States, with not unequal pace, all contribute their annual quota to the formidable list.

Report of the Committee on Jurisprudence and Law Reform, 2 ANN. REP. A.B.A. 193, 203-204 (1879).

At the same meeting, Edward J. Phelps found the law to be "confused and distracted with a multitude of incongruous and inconsistent precedents that no man can number." E.J. Phelps, Annual Address, 2 ANN. REP. A.B.A. 173,175 (1879). 
precedent." 297 In addition, wide publication provided the best check on wayward judges: "No judge is apt to decide a case rashly or corruptly, or against the known law, if he knows that his decision will be exposed to public notice and criticism." 298

In April 1879, after three years of publishing mostly Minnesota decisions in newspaper format, ${ }^{299}$ the West Publishing Company of St. Paul responded to the dilemma lawyers faced in wanting access to all cases, but feeling burdened by costs of the volumes that held them by offering a regional compilation of cases for Iowa, Michigan, Minnesota, Nebraska, Wisconsin, and the Dakota territories under the title: Northwestern Reporter. The new reporter was praised in the legal journals and newspapers for its low price, compactness, and promptness. An 1880 review noted how quickly new cases from the five jurisdictions were available in pamphlet form, then in full volumes. ${ }^{300}$ The Ohio Law Journal concluded that West had reached publishing's "ultima thule of cheapness and perfection." 301

West followed the Northwestern Reporter with the Federal Reporter (including cases from lower federal courts) in 1880, the U.S. Supreme Court Reporter in 1882, and the Pacific Reporter in 1883. When the Pacific Reporter was introduced, the American Law Review proclaimed a new era of cheap law books, ${ }^{302}$ and urged West to extend its coverage to other parts of the country. ${ }^{303}$ The Atlantic Reporter and the Northeastern Reporter both began publication in 1885. Facing competition from other publishers, in August 1885 West announced plans to cover all remaining states. ${ }^{304}$ Its versions of the reports succeeded in the marketplace because they were published

${ }^{297}$ A Few Words about Many Reports, 6 ALB. L.J. 331, 331 (1872). In 1870, the Journal found recent reports of the New York Court of Appeals to be "an outrage upon the court, the profession, and the world." See The Reports of the Courts of Appeals, 1 ALB. L.J. 265, 265 (1870). In 1871, it criticized the reports of southern states in comparison to those of the north. See Some Notes on Southern Decisions and Reports, 4 ALB. L.J. 117, 117-18 (1871).

${ }^{298}$ Id. The article closed by pointing out: "We never hear the complaint made that there are too many books published in the other professions and sciences, ... and yet we complain of too many books on the law, in the ashes of which it is said are taken up, "the sparks of all sciences in the world."' Id. at 332.

${ }^{299}$ West's newspaper was published between 1876 and 1879, first as The Syllabi, then as The Northwestern Reporter. See W.E. Butler, John Briggs West and the Transformation of American Law Reports in THE SYLLABI: GENESIS OF THE NATIONAL REPORTER SYSTEM iii, viii-xii (2011).

300 The Northwestern Reporter, 14 AM. L. REV. 717 (1880). See also Review of Northwestern Reporter, Vol. II, 4 VA. L.J. 642 (1880)

${ }^{301}$ New Books, 1 OHIO L.J. 39 (1880).

302 Notes, 17 AM. L. REV. 1000, 1001 (1883). In an immediately following note regarding Bancroft \& Co.'s new West Coast Reporter, the Review suggested that West either "consolidate with the Bancrofts or to retire from that field of enterprise." Id. at 1002.

303 The Pacific Reporter, Vol. 2, 18 AM. L. REV. 537 (1884).

${ }^{304}$ William W. MARVIn, West Publishing Co.: Origin, Growth, LEADERShIP 42 (1969) (official West Company history). The same month, in an article titled “The Revolution in Law Reports," The Nation reviewed lawyers' complaints about the law reports and called for "publication of one series to contain all the State reports, issued under responsible editorship-something after the pattern of the present English 'Law Reports,' then praised West, which it described as "a fledgling outfit," for its plans to cover all state and federal courts, noting competition from other publishers. The Revolution in Law Reports, 41 THE NATION 167, 167 (1885). In 1885, an observer noted that eleven states were covered by two or three companies' "schemes," presumably in addition to the official reports." The New "Reporters," 19 AM. L. REV. 930, 932 (1885). 
quickly, compactly and in standardized format for all jurisdictions. ${ }^{305}$ By 1888 , all competing regional reporters had ceased publication. ${ }^{306}$

In addition to their success against other commercial reporters, West's reporters also provided better access to new cases than the professional journals and "undercut the reason for being of many law magazines." Some established journals continued, but "their day was almost done."307 After the Harvard Law Review began publication in 1887, student-edited, university-sponsored law journals edited by students became the primary venues for commentary and legal scholarship in law. ${ }^{308}$ None of the late nineteenth century university law reviews published reviews of new volumes of reports.

Well before the first law school journals, reviews of new reports in the professional journals had diminished in number and substance compared to earlier in the century. By the 1870s, few lawyers or others viewed the law reports as literature in the ways James Kent had in 1826: worthy of study by scholars of taste and literature, worth reading for their drama and displays of great feeling. There were now too many of them and lawyers were too consumed with the complexity of modern law to dwell on the literary virtues of court opinions. Nor did the reviews still offer the commentary on the law and its role in society they had in early literary reviews such as the North American Review, then in the American Jurist and other legal journals.

Earlier in the century, however, review of reports, often written by prominent lawyers, contributed to national discourse regarding the role of the reports and the importance of their publication, and helped solidify the place of the common law in the new Republic. The first reviews initiated debates over such questions as what cases should be published and how much subsidiary material such as oral arguments should be included. As early as 1806, when there were still only a few volumes of published American reports, a reviewer worried about effects of the "multiplicity of modern law books" on legal practice, even as others advocated for publication of all federal and state reports, and the appointment of official reporters in all states. In the 1820s, literary journals provided a forum for reviewers of newly published reports to make impassioned defenses of the common law against advocates of codification. Later, despite their main focus on making new cases available to lawyers, many specialized legal periodicals included commentary

\footnotetext{
${ }^{305}$ By publishing all available opinions from each court and eliminating publication of oral arguments, West also effectively put to rest decades-long debates on questions of the reports' content. See POPKIN, supra note 13 at 98 100 for nineteenth century state practices regarding selective publication of cases and publication of arguments or summaries of arguments.

${ }^{306}$ For specific dates, see MARVIN, supra note 304 at 43, 47-48.

${ }^{307}$ LAWRENCE M. FRIEDMAN, A HISTORY OF AMERICAN LAW 546 (1973). See also Shepard, supra note 213 at 44 (noting that West's Southeastern Reporter and its "systematic release of advance sheets of all opinions of the Court of Appeals of Virginia, [eliminated] much of the raison d'etre of publications like the [Virginia Law] Journal, which subsisted almost wholly upon the printing of recent case reports."). Berring suggested that because the law schools subsidized their journals' publication costs as an educational cost, they priced the commercial journals out of business. Berring, History and Development, supra note 18 at 8.

${ }^{308}$ See Swygert and Bruce, supra note 18 at 778-87. The American Law Record greeted the appearance of the Harvard Law Review by noting its "very creditable appearance," also observing that because "the system of weekly reporters has been carried to such perfection by the West Publishing Co., of St. Paul, and the Lawyer's Co-operative Publishing Co., of Rochester, there is no great demand for legal periodicals in addition to those already in the field." The Harvard Law Review, supra note 154. The American Law Record itself ceased publication with its June 1887 issue, in which the comment appeared.
} 
and reviews as well, often debating how improvements in reporting might reduce the financial and other burdens the growing number of reports posed for lawyers.

After the Civil War, fewer journals reviewed the reports, and the practice essentially ended after West reporters blanketed the country in the 1880s. Prior to the changes in legal publishing in the last years of the nineteenth century, however, legal practitioners and scholars alike relied on commercially-produced legal periodicals, both for the newest cases and for commentary and scholarly articles by major thinkers. Some of those journals remain "veritable motherlodes of information regarding nineteenth century legal thought." ${ }^{309}$ And some of the scholarship they hold was published in book reviews and reviews of new volumes of reports.

${ }^{309}$ Berring, History and Development, supra note 18 at 6. 


\section{Appendix: \\ Nineteenth Century American Legal Periodicals*}

American Law Journal and Miscellaneous Repertory, 1808-1817

Carolina Law Repository, 1813-1816

Examiner [New York], 1813-1816

New York City Hall Recorder, 1816-1822

New York Judicial Repository, 1818-1819

Journal of Jurisprudence, 1821

Annual Law Register of the United States, 1822

Journal of the Law School [Needham, Va.], 1822

United States Law Journal, 1822-1826

United States Law Intelligencer and Review, 1829-1831

American Jurist and Law Magazine, 1829-1843

Carolina Law Journal, 1830-1831

Journal of Law, 1830-1831

Jurisprudent, 1830-1831

City-Hall Reporter and New York General Law Magazine, 1833

Law Reporter / Monthly Law Reporter, 1838-1866

Hunt's Merchant's Magazine and Commercial Review, 1839-1861

Louisiana Law Journal, 1841-1842

Journal of Banking, 1842

Pennsylvania Law Journal / American Law Journal 1842-1852

New York Legal Observer, 1842-1854

Legal Intelligencer, 1843-date

American Law Magazine, 1843-1846

Western Law Journal, 1843-1853

American Themis, 1844

Southwestern Law Journal, 1844

Code Reporter, 1848-1852

Western Legal Observer, 1849

New Constitution, Columbus Ohio, 1849

Olwine's Law Journal, 1849-1850

Monthly Legal Examiner [New York], 1850

United States Monthly Law Magazine / Livingston's Monthly Law Magazine, 1850-1856

American Law Register / University of Pennsylvania Law Review, 1852-date

Pittsburgh Legal Journal, 1853-1999

Weekly Law Review, 1855

Cleveland Law Record, 1856-1857

Guigon Quarterly Law Journal [Richmond], 1856-1859

Quarterly Law Journal / Quarterly Law Review [Richmond], 1856-1861

National Law Reporter [New York], 1857

Monthly Law Magazine Reuben Voss' New Lawyer, 1858

* The list includes American legal periodicals that started publication between 1800 and 1899, as found in the HeinOnline Law Journals Library, http://www.heinonline.org/HOL/Index?collection= journals, and in Pauline E. Gee, App. IV: List of Anglo-American Legal Periodicals, in Frederick C. Hicks, Materials and Methods of Legal Research 512 (3d ed.1942). Journals with title changes are listed under their original titles. Twelve titles in the Hein database deemed not to be law journals are not included. Twenty titles from Gee's list of periodicals are also listed as Pennsylvania Miscellaneous Reports in Grace W. Bacon, List of American Law Reports in Hicks 484, 505-07 (3d ed. 1942). Suggestions for corrections or improvements will be gratefully accepted. 
New York Daily Law Gazette, 1858

People's Legal Adviser and Law Reformer [Utica], 1858

Weekly Law Bulletin / Law and Bank Bulletin / Weekly Law Gazette [Cincinnati], 1858-1860

Western Law Monthly, 1859-1863

New York Daily Transcript, 1859-1872

Legal and Insurance Reporter [Philadelphia], 1859-1899

Luzerne Legal Observer, 1860-1864

Weekly Transcript [New York], 1861-1861

Legal Observer [Scranton], 1861-1862

Legal Adviser [Chicago], 1861-1920

California Law Journal, 1862-1863

Banker and Tradesman 1863-date

Law Review (Quarterly), Albany, 1866

American Law Review / United States Law Review / New York Law Review, 1866-1940

Pacific Law Magazine, 1867

Gazette and Bankrupt Court Reporter [New York], 1867-1868

National Bankruptcy Register, 1867-1882

Western Jurist, 1867-1883

Baltimore Law Transcript, 1868-1870

Law Times (U.S.) Courts Reports / American Law Times Reports, 1868-1877

Chicago Legal News, 1868-1925

Bench and Bar, 1869-1874

Lancaster Bar, 1869-1883

Legal Gazette [Philadelphia],1869-1876

Legal Opinion [Harrisburg], 1870-1873

Pacific Law Reporter, 1870-1877

Albany Law Journal, 1870-1909

Luzerne Law Journal, 1871

Indiana Legal Register, 1871-1872

United States Jurist, 1871-1873

Insurance law Journal, 1871-1938

Maryland Law Reporter, 1872

Southern Law Review Old Series / New Series, 1872-1882

American Law Record, 1872-1887

Daily Register [New York], 1872-1889

American Civil Law Journal, 1873

Law Times [Scranton Pa.] (OS/NS), 1873-1875

Legal Chronicle: Reports of Cases Decided in the Supreme Court of Pennsylvania, 1873-1875

Bench and Bar Review / Forum, 1874-1875

Weekly Jurist / Monthly Western Jurist / Monthly Jurist, 1874-1881

Copp's Land Owner, 1874-1892

Central Law Journal, 1874-1927

Albany Law School Journal,* 1875-1876

Michigan Lawyer, 1875-1879

Syllabi [St Paul], 1876-1877

Law and Equity Reporter, 1876-1878

Weekly Law Bulletin / Weekly Law Bulletin and Ohio Law Journal [Cincinnati], 1876-1921

Arkansas Law Journal, 1877

Tennessee Legal Reporter / Legal Reporter, 1877-1879

Texas Law Journal, 1877-1882

San Francisco Law Journal / Pacific Coast Law Journal / West Coast Reporter, 1877-1886 
Virginia Law Journal, 1877-1893

Lackawanna Bar, 1878

California Legal Record, 1878-1879

Chicago Law Journal, 1878-1879

Cleveland Law Reporter, 1878-1879

Memphis Law Journal, 1878-1879

Susquehanna Legal Chronicle, 1878-1879

Southern Law Journal and Reporter, 1878-1881

Quillets of the Law, 1878-1881

New York Monthly Law Bulletin, 1878-1883

Wisconsin Legal News, 1878-1884

Maryland Law Journal and Real Estate Record, 1878-1889

Missouri Bar, 1879

Patent Law Review, 1879-1880

Pennsylvania Law Record, 1879-1880

Illinois Law Record / Real Estate and Law Record, 1880

Central Law Monthly, 1880-1882

Colorado Law Reporter, 1880-1884

Ohio Law Journal [Columbus], 1880-1884

Criminal Law Magazine / Criminal Law Magazine and Reporter 1880-1896

Kentucky Law Reporter, 1880-1908

Law Register [Chicago], 1880-1909

Law Central [Washington, D.C.], 1881-1881

Northwestern Law Journal and Real Estate Reporter, 1881

Monthly Journal of Law [Washington, D.C.], 1881

Kentucky Law Journal, 1881-1882

Alabama Law Journal, 1882-1885

Texas Law Reporter, 1882-1885

Denver Law Journal, 1883-1884

Indiana Law Magazine, 1883-1885

Texas Law Review, 1883-1886

Brainard's Legal Precedents in Land and Mining Cases, 1883-1889

Medico-Legal Journal, 1883-1933

Georgia Law Journal, 1884

Mercantile Law Journal, 1884

American Law Journal [Columbus], 1884-1885

Tax Law Reporter, 1884-1885

Daily Law Record [Boston], 1884-1887

Georgia Law Reporter, 1885-1886

Southern Law Times, 1885-1886

Columbia Jurist, 1885-1887

Kansas Law Journal, 1885-1887

Criminal Law Reporter, 1886

Michigan legal News, 1886

Mercantile Adjuster and the Law and Credit Man, 1886-1903

Trade Mark Record, 1886-1914

Lehigh Valley Law Reporter, 1887-1887

Western Legal News, 1887

Brief [New York], 1887-1888

Chicago Law Times, 1887-1889

Denver Legal News, 1887-1889 
Law Librarian, 1887-1890

Railway and Corporation Law Journal, 1887-1892

Columbia Law Times, 1887-1893

Brief [Phi Delta Phi], 1887-1978

Harvard Law Review, 1887-2011

New York Law Journal, 1888-1832

Kansas City Law Reporter, 1888

National Law Review, 1888

Legal News [Sunbury Pa.], 1888-1889

Advocate, a Weekly Law Journal [Minneapolis], 1888-1890

Law Student's Monthly, 1889-1890

Law Magazine for Lawyers and Laymen, 1889-1890

Current Comment and Legal Miscellany, 1889-1891

Gourick's Washington Digest [D.C.], 1889-1909

Green Bag, 1889-1914

American Legal News, 1889-1925

Banking Law Journal, 1889-1963

Law Book Record, 1890

Nebraska Law Journal, 1890-1891

Students Law Exchange / Washington Law Exchange, 1890-1891

National Corporation Reporter, 1890-1932

Surrogate, 1891

Railway Law and Legislation, 1891

Northwest Law Journal [Seattle], 1891-1892

Counsellor: the New York Law School Journal, 1891-1896

Intercollegiate Law Journal / University Law Review, 1891-1897

Law Bulletin of the State University of Iowa / Iowa Law Bulletin / Iowa Law Review, 1891-date

Yale Law Journal, 1891-date

Nebraska Legal News, 1892 - 1949?

Law Library [Milwaukee], 1892

San Francisco Legal News, 1892-1895

Michigan Law Journal, 1892-1898

Lawyer and Credit Man, 1892-1899

Northwestern Law Review, 1893-1896

Minnesota Law Journal, 1893-1897

University Law Review, 1893-1897

Law Book Adviser: A Journal of Legal Bibliography, 1893-1897

American Lawyer, 1893-1908

Law Student's Helper, 1893-1915

Cornell Law Journal, 1894

Law Book News: A Monthly Review of Current Legal Literature and Journal of Legal Bibliography, 1894-1895

Rosenberger's Pocket Law Journal, 1894-1900

Toledo Legal News / Ohio Legal News, 1894-1901

Commercial Lawyer, 1894-1902

Legal Bibliography, 1881-1913

Case and Comment, 1894-1990

Pennsylvania Law Series, 1894-1896

Wayne County Legal News / Detroit Legal News, 1894-1916

West Virginia Law Quarterly, 1894-1932

West Virginia Law Review, 1894-date 
New York Law Review [Ithaca], 1895

Magistrate and Constable, 1895

Western Reserve Law Journal, 1895-1901

Kansas Lawyer, 1895-1911

Virginia Law Register, 1895-1915

Kansas City Bar Monthly, 1895-1917

Chicago Law Journal Weekly, 1896

Indiana Law Student, 1896

Club, Bench, Bar, and Professional Life of Rhode Island, 1896

Northwest Law Journal [Fargo], 1896

Boston Law School Magazine, 1896-1897

Friend at Court, 1896-1898

New York Monthly Law Record, 1896-1898

Boston Legal News, 1897

Docket [Lebanon, Pa.], 1897-1898

Legal Counselor [Chicago], 1897-1898

Legal Adviser: Monthly Law and Business Magazine, 1897-1899

Law Notes, 1897-1946

Forum / Dickinson Law Review / Penn State Law Review, 1897-date

Wisconsin Bench and Bar, 1898

Law Student: A Journal Serving the Interests of the Law Students of America, 1898

Indiana Law Journal [Indianapolis], 1898-1899

National Bankruptcy News and Reports, 1898-1901

Detroit Legal Journal, 1898-1906

Justice of the Peace [Strasburg, Pa.], 1899-1907 